\title{
Attributions on the Performance of the National Qualifying Examination for School Heads: An Exploratory Study
}

\author{
Gabriel Tingson Galleposo
}

Guintolan Elementary School, Payao Zamboanga Sibugay, Philippines

\begin{abstract}
There is a very limited number of studies on why majority of school heads who took the National Qualifying Examination for School Heads (NQESH) failed, thus the necessity to conduct this study. It explored the factors that influenced the ratings of NQESH through exploratory sequential mixed methods involving 102 school heads in the 1st Congressional District of Zamboanga Sibugay. The qualitative data gathered from 10 respondents through face-to-face interview and focus group discussion arrived at the factors that affected NQESH performance, namely: luck, ability, strong desire, physical state, task difficulty, emotional state, mental state, and effort. The quantitative data gathered from 92 respondents through a researcher-made survey instrument were subjected to Pearson Coefficient of Correlation, t-test and stepwise regression. It is concluded that the internal locus of control factors such as ability, effort, physical state, and NCBS-SH domains along with the external locus of control factors such as luck, and task difficulty, wield a significant influence in the NQESH performance. Educational attainment, level of management training attended, and marital status were also differentiating factors in NQESH performance. Based on the regression analyses results, NCBS-SH, management training, ability, and task difficulty are good predictors of NQESH performance. NCBS-SH competencies can improve and enhance school management ability. Dynamic professional development and more developed critical and analytical skills are definitely needed to pass the NQESH.
\end{abstract}

Keywords: NQESH performance, NQESH review model, internal and external locus of control.

\section{Introduction}

Republic Act No. 9155 states that every public elementary and secondary school of the country shall be managed by a school head who is responsible for the financial affairs of the school, curriculum implementation, maintenance and improvement of the physical facilities, and program innovations.

In view of this, the Department of Education (DepEd) issued DepEd Order, hereinafter referred to as D.O., No. 42 (2007) revising the guidelines on selecting applicants for a school head position. The order specified the scope of leadership dimensions a school head must possess such as educational leadership, people leadership, and strategic leadership. Educational leadership, according to RA 9155, is the ability of the school heads to devise measures and activities that will ensure the implementation of the curriculum along with platforms of activities that will enhance its delivery. They are expected to convey the vision and mission of the school to all shareholders in order to achieve such undertakings.

People leadership pertains to the ability of the school head in establishing a sound work relationship with the school community and in building partnership with the other government and non-government organizations to achieve the planned goals and objectives. On the other hand, strategic leadership pertains to the ability of the school head to view issues and concerns of the school from a perspective that is globally acceptable, and in spending resources efficiently by ensuring its maximum utilization for the benefit of all concerned.

The DepEd Order further tasked the National Educators Academy of the Philippines (NEAP) in coordination with the National Education Testing and Research Center (NETRC) to develop the first National Qualifying Examination for 
Principalship (NQEP) which will be administered nationwide to evaluate and measure the applicants' capacity for a school principal position in terms of the three leadership dimensions.

In November 2008, the first NQEP was conducted nationwide in each region in its own testing center. The examination was conducted in Zamboanga City for Region IX. It covered the three leadership dimensions as well as English language proficiency and reading comprehension. The result was released on March 13, 2009. There were only $21(2.30 \%)$ passers out of 912 takers from the Division of Zamboanga Sibugay and the researcher was among them.

In April 2009, D.O. No. 36 (2009) was issued stating a strict compliance in passing the NQEP as basis for appointment for a school principal position. It itemized in detail the standard qualifications of the examination applicants in terms of position and years of experience. The examination was conducted in November 2009, and when the result was released, Zamboanga Sibugay Division had only 1 passer.

In its pursuit to become globally competitive and in providing the nation with competent educational leaders, the Department of Education issued D. O. No. 32 (2010) stating nationwide adoption of the National Competency-Based Standards for School Heads (NCBS-SH) which defines performance standards of the school heads to ensure that they will perform to the best of their ability insofar as the scope of school-based management is concerned.

Along with this order was the profound change in the NQEP. It was renamed National Qualifying Examination for School Heads (NQESH). NEAP streamlined the examination focusing only on the seven domains of NCBS-SH and excluded English language proficiency and reading comprehension (D.M. No. 140, 2009). The streamlined examination consisted of 200 items which were anchored on the seven NCBS-SH domains. In 2017, the seven domains of NCBH-SH were clustered into three and a test taker must obtain a rating of not less than $70 \%$ in each of the clusters to pass the examination as stipulated in D. M. No. 93 (2018). From 2010 to present, the NQESH has remained the surmounting obstacle for a school principal position.

Thousands of aspirants for school principal position took the examination every year but only a few made it. The 2018 examination has the lowest passing rate of $0.64 \%$ nationwide. Only $148(0.64 \%)$ out of 23,000 test takers passed the examination. The researcher firmly believes that every school head has the elemental knowledge of the breadth and depth of the standard's framework since a series of training has recently been conducted by the NEAP focusing on the domains of the NCBS-SH, and yet, the result was not satisfactory.

Concerned with the result of NQESH, the researcher conducted this study to explore the factors that affected the performance of the school heads in the examination. It will uncover the attributions why they passed or failed in the examination, provide explanations on their performance and present a model that will serve as basis in school heads review program.

\section{Literature Review}

\subsection{Review of Related Literature}

This part reviews relevant literature on the factors that influenced the school heads performance in the NQESH. There appeared to be only one current study that focused on this particular topic. It compared the school heads' instructional, supervisory and administrative skills with the result of the NQESH. Hence, other several qualitative and quantitative researches on student performance in board examinations in both national and international setting were reviewed.

\subsubsection{International Studies}

In trying to understand the lived experiences of Graduate Nurses (GNS) with Multiple National Council Licensure Examination-Registered Nurse (NCLEX-RN) failure in Indiana University of Pennsylvania, USA, Silva (2015) discovered that one of the themes why graduate nurses failed in the licensure exam is the pathological fear of examination. There were students who panicked at the mention of examination. Some even fainted in the examination 
hall. They suffered from examination phobia which is caused by fear while taking the examination. Fear causes an individual to lose his ability to recall stored information and understand what he reads. It is often the result of poor planning and lack of preparation in taking the test. The other themes such as blaming, being alone, needing support and assistance were of equal importance. After failing the NCLEX-RN, the graduate nurses felt abandoned and left alone. They blamed not only themselves but the nursing program and nursing faculty members. They believed that they were not prepared sufficiently to be successful in taking the examination.

In a similar study, Griffiths et al. (2004) investigated 21 participants who failed in the NCLEX-RN at least once in a two-phase retrospective research study. The factors they discovered which had an adverse impact on the result of examination were insufficient preparation in programs undertaken, unfocused study practices, and responsibilities of the family.

In comparison, the dissertation of McFarquhar (2006) wanted to understand the experiences of success and failure of NCLEX-RN from those who passed the examination after multiple attempts. The researcher sought not only the experience of failure but also the participants' perceptions of what aided in their success. The results were divided into five categories: affective experience, conative experience, cognitive experience, experience and failure, and experience and success. Affective experience deals with the person's feelings about their behaviors. The identified pattern of responses was knowledge-seeking behaviors. Each of the participants revealed an initial temporary decrease in psychological and sociological behaviors that included disappointment, depression, and avoidance. All participants agreed this was temporary and was replaced with confidence as they aspired toward their goals.

The concept of conation involves the person being able to identify and apply innate behaviors, such as an inclination, a drive or a wish, towards success. Individuals must strive to succeed and must have an active mental state that pushes them to perform better and achieve their goals. The patterns included striving that enabled success, innate desire to succeed, and external factors such as family, friends, institutions, and meaningful acts (McFarquhar, 2006). All participants of his study had a strong innate desire to succeed and they utilized external factors to assist them to succeed. He also discovered that in addition to the person needing appropriate affective and conative qualities, the participants also needed the proper cognitive traits. They needed adequate reasoning skills and knowledge to become successful. With cognition, they needed to strive for success through intellectual behaviors. For the cognitive experience, the study revealed the participants' need for intentional interventions to succeed.

In the category of experience and success, the study provided an insight from the participants about what helped them to become successful. The key theme was perseverance. The participants further described this as knowing and understanding what to expect on the examination. The participants' perceptions included the failures in assisting them to know what to expect and how to prepare for the next examination. The participants needed to acquire the understanding of when to retest. Retesting before the participant was ready could lead to another failure. Understanding when an individual is ready needs to come from the individual. Failure in an examination is an individual experience that must be overcome by the individual. Success depends on the individual taking responsibility for their own success (Poorman \& Webb, 2000).

Another study conducted in Jordan by Al-Zoubi and Younes (2015) identified causes of poor educational achievement and low score in examinations from the perspective of parents and teachers. They pointed out that emotional and psychological problem like money worries, family problems and physical stress were factors that significantly affected the performance of students in taking examinations. They also found that test anxiety played a great influence in examination performance. Test anxiety is a condition that individuals experience as they take the test. It arises from fear of not passing the examination. This emotion can affect the mental faculties of the individual which could result to inability to concentrate and remember basic facts which are important in answering the questions. These disturbances are the result of an individual's worrying of not being promoted and their concern for their social life which will be affected if they fail the examination.

In addition, Vaz et al. (2018) conducted a study on the factors influencing examination anxiety in selected universities in India. The data showed that a staggering 39\% of the participants experienced test anxiety during the examination. The result of their study identified four factors that influenced examination anxiety which are the process of learning, 
individual insights of the examination, the pattern from which individuals gain their learning, and an over-expectation regarding the outcomes of such learning.

Similarly in Canada, Baker-Doyle and Petchauer (2015) reported that test anxiety predicted performance success in examination. They reported that individuals, who are very confident in their points of views, had high level of selfreliance and exerted effort to attain expertise, exhibited a considerable chance of passing an examination.

It was also found in another study conducted in Lahore-Pakistan by Sadiq and Saeed (2017) that testing environment played a significant role in affecting the test takers' examination results. The study discovered that students felt disheartened by the physical condition of the testing room such as inadequate lighting and ventilation. The study also uncovered that test materials created tension among the test takers due to typographical errors and that the conduct of the examination caused them distress.

Exposing test takers to a mock examination had shown a great help as reported by Childs et al. (2002). Their study exposed students to different testing environments from all possible situations and trained them to be familiar with the conditions that might happen during the actual examination. Gulek (2003) added that teachers must also possess acceptable level of expertise in the areas that will be assessed during the examination including the type of tools used to measure the students' mental ability and competence so that they can provide significant insights in the conduct of the mock exams.

In the same way, test-taking tutoring sessions was also a factor in achieving good licensure examination results as revealed by the study of Mee (as cited in Sobotka, 2017). The sessions included time-pressured tests. Questions were constructed based on the competencies expected to be measured during the examination and subjected the respondents to different testing environments.

\subsubsection{National Studies}

Closely related to this research is the study that aimed to determine the predictors of performance in the NQESH in the six divisions of Pangasinan. Ceralde (2014) found that those who passed the examination had a "highly favorable" attitude towards the teaching profession, reliably "high" emotional intelligence, and "high" motivational orientation with particularly "very high" interest in managing the school and dependably "high" learning practices. His study showed that age, sex, position before the test, highest educational attainment, specialization, years in the service, number of times NQESH was taken, experience in managing school, motivational orientations, and learning strategies were contributory factors in passing the test but did not significantly predict NQESH performance. Additionally, Jalagat (2016) found that marital status is a non-significant factor in determining the performance of test takers in the CPA board examinations.

Another study on why students failed in board examinations by Olaniran (2013) revealed that ignorance of what the examination demands, absence of examination techniques, poor planning and inadequate preparation were the causes. Students take examinations ill-prepared. They have very little knowledge on the appropriate techniques to apply in answering questions and showed no concern of the time spent in an item. These factors were found to have robbed the students much of their chances to succeed. He concluded that attitude towards examination affects performance ultimately.

In the same study, laziness and procrastination are two significant factors that contributed to the failure of students in board examinations (Olaniran, 2013). Laziness is unwillingness to work; procrastination, on the other hand, is to keep putting off an action. It is leaving until later date what one ought to do now. These two related factors accounted for the failure of many students in examinations. These students did not religiously appear in their classes; did not take notes nor read prescribed textbooks. Similarly, many did not participate in continuous assessment test and refused to do assignments or homework - behaviors that have great impact on the examination outcomes.

Another study by Visco (2015) found that poor concentration and lack of mastery of subjects played a significant role in passing or failing the examination. He reported that the unimpressive performance of many students record was 
traceable to this important factor. Poor concentration resulted in poor learning during class and personal study periods. It is also caused by lack of mastery of the subject being learned.

Psychologists noted that poor concentration of an individual is a product of interferences which can be eliminated once the individual is able to identify them. Poorman and Webb (2000) explained that students need to concentrate to have full understanding of what they study, remember the lessons learned from their studies and recall these facts as required by the situation at hand. This is affirmed by one of the findings of McFarquhar (2006). He stated that students often found it frustrating whenever they cannot recall or remember some important items of information required to answer a question in an examination. He further explained that the ability to recall facts instantaneously is an asset to a student while the inability to recall the same is his most horrible enemy.

A similar study by Maghuyop (2015) on librarian licensure performance in Davao City reported that lack of confidence is a significant factor that affected a student's performance in the board examination. A student who did not prepare well for an examination, who studied only half the syllabus and just had a fair or shallow knowledge of the subject lacked the confidence and composure required to face the examination.

Moreover, Dagdag et al. (2017) discovered several factors that caused failing scores of the teachers' board examinees. One of these factors was their failure to read and follow instructions. The instructions or rubrics constitute the laws of the examination because they provide very important guidelines (a set of do's and don'ts) from the examiner to the examinees. They discovered that many examinees ended up wasting precious time doing things that were not necessary.

Another factor that Dagdag et al. (2017) found to be affecting the results was the examinee's inability to interpret the questions. They clarified that examiners use key words to construct every question and that every area has its particular language and a set of key words. They concluded that many students failed due to their lack of ability to understand the gist of each of the questions. They also found that poor time management that led to unfinished work and left no time for review as another factor. This factor constitutes a major problem to many students who took the examination.

Finally, a study conducted at Rizal Technological University by Allaga and Pachejo (2011) found that several students left venues of examination crying due to time constraints. They often complained that time was not adequate. The researchers rationalized that the statement was not generally true since many other test takers who prepared themselves for the test had finished the exam ahead of time and afforded themselves with an ample time in reviewing their answers.

The reviewed literatures identified several factors that affected the performance of test takers in examinations. Test anxiety, poor time management, physical stress, emotional and psychological problems were the prominent factors. Lack of confidence, insufficient preparation to take the test, laziness and procrastination, and lack of mastery of the subjects were also identified as the key factors that contributed to students' unsatisfactory performance in the examination. Other factors such as the testing environment, poor concentration, inability to follow instructions and interpret the gist of the questions were also noted to contribute to failing marks.

There were also factors found to have contributed to a favorable performance of the students. These are the innate desire of the students to succeed, adequate reasoning skills and knowledge, perseverance by knowing and understanding what to expect on the examination, tutorials and positive learning practices. Motivational orientations and encouragement from families and friends were also noted as significant factors that influenced the performance of test takers in the examination.

This research would like to find out whether the factors that influenced the results of the board examinations are true and relevant to the participants of this study. 


\subsubsection{NCBS-SH Domains}

Domain 1: School leadership. School leadership management refers to the administration of a school to provide the best possible conditions for staff, teachers and students to work in the most efficient way and maximize the utilization of available resources. In essence, school leadership means creation of an effective, high-functioning professional community committed to provide quality education (Gezahegn, 2019). Education in the Philippines is managed and regulated by the Department of Education (DepEd) that uses a School-Based Management system which governs the education system at school level, including the curriculum used and the allocation of funds (Wooi, 2015).

School leaders are expected to demonstrate collaborative decision making and putting into practice the principle of shared governance. They are also expected to maintain good relations with the school community and possess conflict management skills which are useful in resolving issues in the school, and establish and maintain an effective feedback mechanism and take the lead in introducing innovative activities to enhance curriculum implementation (Punsalan, 2012; D.O. No. 32, 2010).

Domain 2: Instructional leadership. This skill involves assessing learning for enhancement or remediation, providing technical assistance to teachers in their class instruction through observing classes. SeameoInnoctech (2009) defines instructional leadership as the act of the school head in ensuring quality of instruction, modeling teaching practice, supervising curriculum, and ensuring quality of teaching resources.

D.O. No. 32 (2010) explicitly stated that the school head is expected to lead in the enrichment of the curriculum through using appropriate technology and is also expected to conduct regular instructional supervision to ensure that teaching pedagogies of teachers are relevant and developmentally appropriate to the level of learners.

Domain 3: Creating a student-centered learning climate. This domain pertains to keeping in mind that the learner is the heart of every learning institution. It ensures their active involvement in experiencing joy within and without the classroom (Ang et al., 2001). As such, school heads are presumed to demonstrate support to the desire of learners to learn more and recognize their diversity, they are also tasked to create and maintain a secure and undiscriminating learning atmosphere that will help promote equal access of opportunities (D. O. No. 32, 2010).

Domain 4: Human resource management and professional development. Effective school heads make certain that the skills of the teachers are developed and enhanced continually to be pertinent in this steadily changing society. Punsalan (2012) reported that effective professional development is on-going which includes training, practice and feedback, and an adequate time for follow-up support. Consistent with the existing DepEd guidelines, In-Service Trainings (INSETs) through School Learning Action Cells (SLACs) are considered to be the best way of promoting professional development at the school level. The school heads are tasked to oversee its implementation and ensure its success.

Domain 5: Parent involvement and community partnership. This domain requires school heads to establish strong and stable partnership with the parents and the community and involve them in the implementation of activities that promote greater results of learning. It obliged them to regularly conduct forums where performance of the school and achievement of learners are reported.

Domain 6: School management and daily operations. It is concerned with the ability of the school heads to take the lead in designing and maintaining the condition of the physical facilities of the school that foster learning. They are to convene with experts on facilities and shall oversee its operations as prescribed by existing guidelines of the department.

In her study of School Management in Cotabato City, Kadtong (2014) stated that there exists a strong relationship between School-Based Management (SBM) implementation and school operations in the areas of communication, decision-making, transparency, school safety and orderly environment, and school equipment and physical facilities. Her finding affirmed that school heads are responsible in maintaining and replacing properties of the school and dispose of properly non-reusable equipment and materials. She concluded that school heads are the sole person accountable for school funds, its appropriation and proper utilization. 
Domain 7: Personal and professional attributes and interpersonal effectiveness. School heads are expected to demonstrate adherence to the acceptable conduct and norms expected from government officials and employees as prescribed by RA 6713 (1989) and observe the ethics of teaching practices as stipulated in RA 7836 (1994).

In Philippine educational setting, school heads work in a unique political and social context. They have many challenges to educate students and to serve their community. Hence, it is imperative for them to institute and preserve valuable network of assistance. The most effective heads develop these networks both within the school system and in their local communities. It is also important to create support communication networks at the district level. Such structures have the potential to provide some stability to the system, allow greater sharing of resources and help establish and develop district resource centers that can share instructional resources and offer targeted professional development. The Department of Education ensures that all levels should institute and practice financial transparency and accountability systems (Brooks \& Sutherland, 2014).

The study of Katz (2004) listed 28 skills that help school heads become effective change agents. These skills are found to be parallel with the domains of the NCBS-SH. He concluded that schools are no longer simply responsible for teaching reading, writing, and arithmetic, but have taken on the roles of caregivers, food providers, teachers of ethics, morality and values, and have undertaken great social responsibility for teaching our children how to exist in modern society. As such, school heads must possess the needed abilities and skills in sustaining these changes. The study concluded that these are clearly the important set of factors for screening individuals who aspire to become school principals.

\subsection{Theoretical Framework}

Weiner's Attribution Theory is used as the framework of this research because it is concerned with the interpretation of the events that contributed to individual's achievement and their relation to their way of thinking and their behavior (Weiner, 1985). The theory states that people try to determine why they do what they do and attribute these causes to certain factors.

Weiner (1985) named that the most important factors that can influence achievement are ability, effort, task difficulty, and luck which in turn are classified into causal dimensions such as locus, stability, and controllability.

Locus of causality describes whether the causes of achievement are internal which are commonly connected with capacity, efficacy, skill, aptitude, and determination of an individual in achieving their goals; or external which are usually linked to factors that an individual attributes the success or failure of their desired goals such as luck and task difficulty.

The second dimension is stability which illustrates how stable the causes are in influencing failure or success of a goal. Stable causal factors are universally interrelated with intelligence and aptitude which are very hard to alter, if altered after all. Unstable causal factors, like for instance the extent of efforts applied toward a goal, can be altered effortlessly. Kovenklioglu and Greenhaus (1978) cited that when an outcome such as poor performance is attributed to a stable cause, such as low intelligence, it is logical to expect that the performance is not going to change in the future. If the same performance is attributed to a less stable factor, such as insufficient effort, the performance could be improved in the future by working harder.

Controllability is the third dimension of attribution. It contrasts causes that one can control, such as skill or efficacy, from causes that one cannot control, such as aptitude, mood, others' actions, and luck. A cause might be internal yet uncontrollable or external but controllable (Weiner, 1985).

Furthermore, Weiner (1985) stated that attributions can establish emotional reactions between achievement and disappointment. Hence, this study is anchored on the principle that success or failure in an examination is attributed to either external or internal factors and that these perceived factors share common properties: locus, stability and controllability. 


\subsection{Conceptual Framework}

It is natural for human beings to be inspired and motivated, and do things that make them happy and satisfied, and successful. It is also but natural for them to attribute their success or failure to a considerable number of causes that influences such circumstance.

In this study, these attributions are classified into two categories. The first category is concerned with the profile of the respondents namely: sex, marital status, age, management experience, present position, highest educational attainment, level of management training, and the number of times failed in the examination while the second category pertains to the factors that emerged to have an influence on the participants' performance in the NQESH such as ability, strong desire, effort, luck, task difficulty, emotional state, physical state, mental state, and NCBS-SH domains. Figure 1 presents the framework of this research.

\section{Factors}

\section{Performance}

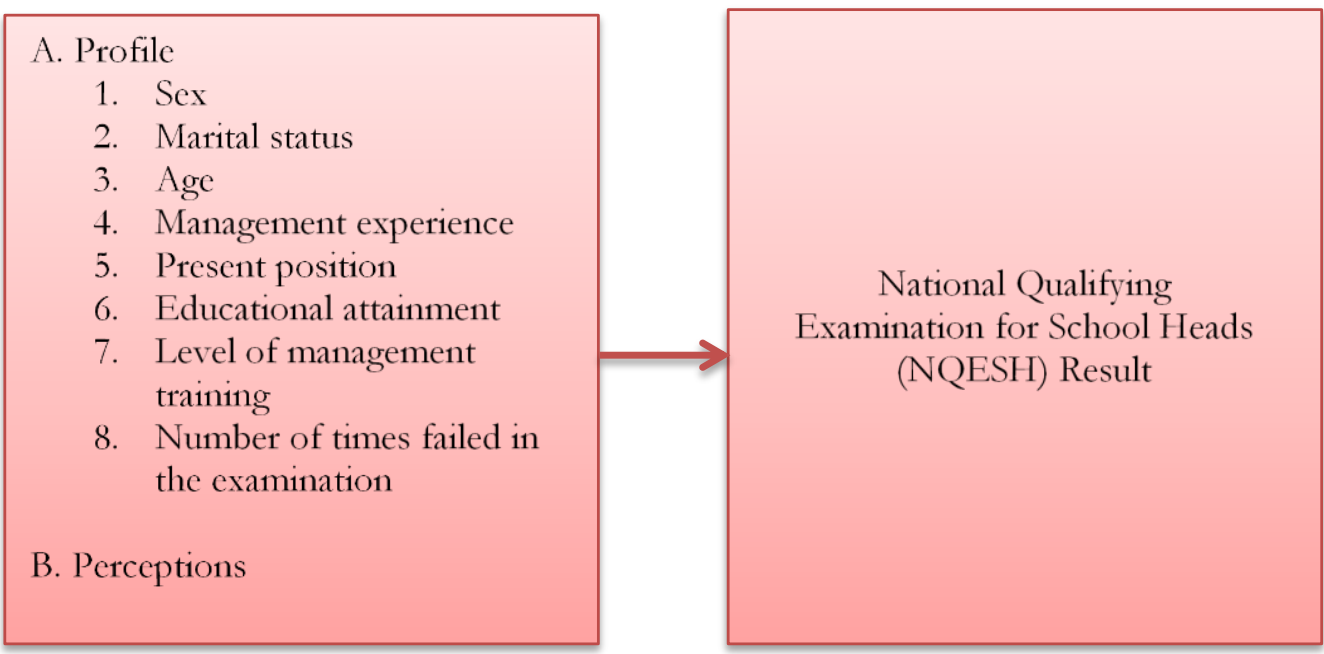

Figure 1. Schema of the study

\subsection{Statement of Purpose}

The goal of this exploratory sequential mixed-methods research is to explore the factors that influence NQESH results and to develop a model for school heads' development program.

\section{Phase 1 - Qualitative Phase}

A. Central questions:

1. Why did you pass/fail?

2. Why is the examination easy/difficult for you?

B. Sub-questions:

1. What part of the test did you feel the hardest?

2. What were your feelings when you took the test?

3. In what way do the questions relate to the daily tasks of the school head?

4. Why was the examination difficult for you?

5 . Why is the examination easy for you?

6 . What preparations did you make before taking the examination?

7. What are the factors you think have influenced in your failing the examination? 
8. What are the factors you think have influenced in your passing the examination?

9. What particular topic did you find most difficult?

10. What will you do if you are going to take the exam again?

\section{Phase 2 - Quantitative Phase}

Based on the factors that emerged in the analysis of the qualitative data, the researcher developed an instrument that answered the following questions:

1. What is the participants' profile as to

1.1. Sex

1.2 Marital Status,

1.3. Age,

1.4. Years of Management Experience,

1.5. Present Position,

1.6. Educational Attainment,

1.7. Level of Management Training, and the

1.8. Number of times failed in the examination?

2. What are the participants' levels of perceptions on their:

2.1. Ability,

2.2. Motivation,

2.3. Effort,

2.4. Luck,

2.5. Task difficulty,

2.6. Emotional state,

2.7. Physical state,

2.8. Mental state, and

2.9. Difficulty of the NCBS-SH domains?

3. Is there a significant relationship between the participants' levels of perception on the emerging factors and their NQESH performance?

4. Is there a significant difference in the participants' NQESH performance when grouped according to:

4.1. Sex

4.2. Marital Status,

4.3. Age,

4.4. Management Experience,

4.5. Present Position,

4.6. Educational Attainment,

4.7. Level of Management Training, and the

4.8. Number of times failed in the examination?

5. What model can be proposed that can serve as basis in creating a development program for the school heads?

\subsection{Scope and Limitations of the Study}

This study explored the factors that influenced the result of the NQESH through a series of face-to-face interviews for Phase 1 and a researcher-made survey questionnaire for Phase 2. Qualitative data were gathered from ten school heads while the quantitative data from 92 school heads. The respondents were sampled from the school heads in the 1 st Congressional District of Zamboanga Sibugay during the school year 2019-2020. 


\subsection{Significance of the Study}

The researcher would like to contribute to the very limited studies conducted on NQESH. The findings and recommendations will serve as basis for conducting skills development program to aspiring school principals while the proposed a model can serve as basis for a review program. Hence, this study can be of significant help to the following:

Top-level Managers in the Division. The proposed statistical model of this study can help the Human Resource Management Division (HRMD) and the Office of the Schools Division Superintendent (OSDS) of Zamboanga Sibugay in providing review programs for school heads in its continuing effort to achieve higher percentage of passers in the examination.

School Heads. The recommendations from this study can help them deepen their understanding of the concepts of School-based Management, their roles as school heads as enumerated in the NCBH-SH and in enhancing their abilities in applying such concepts in day-to-day school operations thereby increasing their chance in passing the NQESH.

The proposed statistical model can also help them realize to harness their full potential and make them their fundamental tool in passing the NQESH.

Teachers. The recommendations of this study can serve as a guide for teachers who aspire to become school heads in capacitating themselves and in performing competently the responsibilities inherent to the position.

Researchers. Since passing the NQESH is now a requirement for promotion to a school principal position, this can serve as reference to other researchers who desire to explore other factors not covered herein, and in their quest of presenting more relevant findings and recommendations of the topic.

\section{Research Method}

This study employed exploratory sequential mixed methods design which is anchored on the philosophical assumption of pragmatic world view (Morgan, 2007). The study underwent a three-phase process (Creswell, 2014). The first phase began by analyzing the qualitative data obtained from interviews and focus group discussions. The second phase was the construction of a survey instrument based on the factors that emerged in the first phase. The last phase was the administration of the instruments to respondents chosen at random. The purpose of this process is to confirm if the factors that surfaced in the qualitative stage are universal to the larger sample of the population.

\subsection{Research Locale}

The province of Zamboanga Sibugay was created by virtue of R.A. 8973 (2000). Section 2 of the same Act states that "there is hereby created a new province from the present Province of Zamboanga del Sur to be known as the Province of Zamboanga Sibugay. The municipalities of Buug, Diplahan, Malangas, Imelda, Alicia, Mabuhay, Olutanga, Talusan, Payao, Siay, Kabasalan, Naga, Ipil, Titay, Rosseller T. Lim and Tungawan comprise the Province of Zamboanga Sibugay."

The province is composed of two congressional districts. The study focused on the school heads of the First Congressional District comprising municipalities of Buug, Diplahan, Malangas, Imelda, Payao, Alicia, Talusan, Mabuhay and Olutanga. There was a total of 210 elementary schools and 29 secondary schools, headed by 236 school heads, $51(21.61 \%)$ of whom were passers of the NQESH.

\subsection{Research Participants}

The researcher selected five school principals from the passers group and five school heads from the non-passers group as sources of data in the first phase. The concepts, ideas and notions reached the level of saturation during the interview of the $9^{\text {th }}$ and $10^{\text {th }}$ participant, so the researcher concluded the interview and started analyzing the data. 
The calculated sample size for the population of 236 school heads at $95 \%$ level of confidence is 133 . Since there were 51 passers of the population and five of them were already interviewed, the remaining number of respondents under this group was 46. Creswell (2014) suggested that there should be an equal number of respondents from the two groups to avoid bias. Consequent to this, there were 46 respondents from the passers group and 46 respondents from the non-passers, totaling 92 respondents. The researcher employed random sampling in the conduct of the survey.

The participants in the qualitative phase were selected based on the following criteria:

A. The five passers:

1. Passed the NQESH in the last five years

2. Presently holds a school (not detailed to division or regional offices)

3. Has no pending administrative case.

B. The five non-passers:

1. Has taken the 2019 NQESH

2. Presently holds a school (not detailed to division or regional offices)

3. Has no pending administrative case.

Participants in the second phase were chosen at random based on the following criteria:

A. NQESH passers:

1. Passed the NQESH in the last five years

2. Presently a school head (either teacher in-charge or head teacher or a school principal); and

3. Has no pending administrative case.

B. NQESH non-passers

1. Presently a school head (either teacher in-charge or head teacher or a school principal)

2. Master Teacher who has been in an acting capacity for at least 6 months.

3. Teacher 3 who has been in acting capacity for at least 1 school year.

4. Has taken the NQESH for the last three years but failed; and that

5. Has no pending administrative case.

\subsection{Research Instruments}

An interview guide was used in the first phase. The participants were interviewed face-to-face at their chosen place and time. The interview was audio recorded and the researcher wrote observations on the actions, reactions, gestures and body language of the participants. The thematic method was used to gather concepts from clusters of ideas obtained from the transcripts of the interviews. These concepts were grouped according to similarities and were given codes, which were grouped once more to identify the emergent factors that were used in designing a survey instrument to measure the participants' level of perceptions on the factors that may affect their NQESH results.

The survey instrument was corrected by an expert of the field in terms of content and relevance. It was then pretested to those who were interviewed, soliciting their opinions about the items. There were a few additional statements that they wanted to incorporate, hence, the researcher revised the instruments to include those items. The questionnaire underwent another round of scrutiny under the critical eyes of the expert. After having been satisfied with the correctness of the revised instrument, it was piloted to 20 school heads in the $2^{\text {nd }}$ Congressional District of Zamboanga Sibugay. The scores subjected to Cronbach Alpha to test for its reliability showed a value of .811 . Hence the questionnaire was very reliable.

\subsubsection{Data Gathering Procedure}

In the first phase of this inquiry, the researcher met each of the respondents and explained the purpose of the visit, explicitly citing the confidentiality of the information, expected outcomes and the possible impact of the study. After the schedule was arranged, the interviews were conducted at an average of one hour and fifteen minutes. 
Before the administering the survey instrument in the quantitative phase, the researcher asked permission and approval from the Schools Division Superintendent to conduct the study. Once the request was approved, the researcher conducted the survey to identified respondents from the nine municipalities of the 1st Congressional District of Zamboanga Sibugay.

\subsubsection{Data Analysis and Interpretation}

The qualitative data were analyzed thematically. Similar ideas from the transcript were grouped together to form the initial codes. These codes were clustered to become properties which in turn were grouped according to similarities to identify the emergent factors. These factors were used in the development of the survey questions in the quantitative phase. Weighted mean was utilized to analyze data obtained from the survey. Pearson's Coefficient of Correlation was used to determine if there was a significant relationship between the participants' levels of perceptions on the factors and their NQESH performance. T-test was used to find out whether there was a significant difference in the participants' performance when grouped according to the profile variables. The results of the weighted mean were interpreted using the following range of values:

$\begin{array}{lll}4.21-5.00 & - & \text { Very High } \\ 3.42-4.20 & - & \text { High } \\ 2.61-3.40 & - & \text { Average } \\ 1.81-2.60 & - & \text { Low } \\ 1.00-1.80 & - & \text { Very Low }\end{array}$

\subsection{Ethical Considerations}

Ethical considerations were given a priority in gathering the data. The following considerations were carefully observed as suggested by Strauss (2001):

Respect for privacy. The personal identities of respondents were kept confidential. The researcher guaranteed confidentiality of respondents' personal information since the interviews were conducted all by himself.

Time and venue. The venue was at the choice of the participants. It was held in their respective offices or at their homes at their most convenient time.

Beneficence. The researcher ensured that the principle of primum non nocere (first, to do no harm) was put first in place before the interview began. This is to guarantee that their identity and answers were strictly kept confidential, and that the audio recordings along with the notes will be destroyed after the research had been concluded.

Voluntary participation and informed consent. All respondents were made aware of the possible outcomes of this study and its impact. The researcher ensured that their participation was totally voluntary and that they acted according to their own free will, without having been coerced nor forced to participate. Their consent was given in an oral form since the researcher met them personally.

\section{Results and Discussions}

Presented in this chapter are the coding processes of the information shared by the participants in the qualitative phase and the analysis and interpretation of the themes and factors that emerged. This is followed by the presentation of the data on the details of the perceived emerging factors in the quantitative phase and the proposed model of this study.

\subsection{Qualitative Phase}

This part presents the thematic analysis of the qualitative data. Thematic analysis is the process of identifying patterns or themes in the qualitative data. The goal of a thematic analysis is to identify themes, that is, patterns in the data that are important or interesting, and use these themes to address the research or say something about an issue (Clarke \& Braun, 2013). 
Initial Coding. The coding process started with transcribing the data gathered from ten participants involving five passers and five non-passers of the NQESH. The data were gathered through face-to-face interview with audio recording ranging from one hour to one hour and fifteen minutes. The interview explored the factors which affected their NQESH rating. These data were based on the grand tour question: Why did you pass/fail the examination?

Table 1 shows how the excerpts of the interview were analyzed, grouped together commonalities and given codes. There are 51 codes generated after thoroughly examining the transcripts. These codes are stated in gerund form to connote action in the data (Charmaz, 2006).

Table 1. Sample Initial Coding

\begin{tabular}{|c|c|c|}
\hline $\begin{array}{l}\text { Code } \\
\text { Number }\end{array}$ & Excerpts from Interview Transcripts & Initial Codes \\
\hline \multicolumn{3}{|c|}{ Q1. Why did you pass the test? } \\
\hline 1 & $\begin{array}{l}\text { P1: Blessing. I asked and prayed God for it } \\
\text { P3: By God's Grace. } \\
\text { P5: It was a blessing from God that I passed the test. }\end{array}$ & Having faith in God \\
\hline 2 & $\begin{array}{l}\text { P2: I did a self-review on the DepEd Orders and on the domains of } \\
\text { NCBS-SH } \\
\text { P3: Self-study and self-review of the SBM Level of Practice, } \\
\text { NCBS-SH and DepEd issuances. } \\
\text { P4: I studied on the competencies of NCBS-SH and relate each } \\
\text { competency to DepEd Orders. }\end{array}$ & $\begin{array}{l}\text { Studying the } \\
\text { competencies of } \\
\text { NCBS-SH and } \\
\text { DepEd Orders }\end{array}$ \\
\hline 3 & $\begin{array}{l}\text { P3: Familiarize the DepEd Orders pertaining to school management } \\
\text { and supervision, and the K to } 12 \text { Curriculum, the School-based } \\
\text { Management Principles and all other DepEd issuances. } \\
\text { P4: Intensive reading of DepEd Orders and the domains of NCBS- } \\
\text { SH, even the night before the exam. } \\
\text { P5: Reviewing readings pertaining to school management, } \\
\text { instructional supervision, financial management, school operations } \\
\text { and the domains of SBM and NCBS-SH. }\end{array}$ & $\begin{array}{l}\text { Reading SBM } \\
\text { Principles, NCBS-SH } \\
\text { and Kto12 } \\
\text { Curriculum }\end{array}$ \\
\hline 4 & $\begin{array}{l}\text { P1: The questions were related to my daily task in the school. } \\
\text { P3: The questions were all application of the DepEd Orders, Laws } \\
\text { and the competencies of NCBS-SH } \\
\text { P5: The situations in each question were all related to my daily } \\
\text { tasks, duties and responsibilities. }\end{array}$ & $\begin{array}{l}\text { Relating questions } \\
\text { to responsibilities and } \\
\text { accountabilities } \\
\text { of the school head. }\end{array}$ \\
\hline
\end{tabular}

Table 2 presents a sample of 51 properties that emerged during the initial coding of the interview transcripts.

Table 2. Emerging Properties

\begin{tabular}{|ll|}
\hline \multicolumn{2}{|c|}{ Properties } \\
\hline 1. & Having faith in God \\
\hline 2. & Studying the competencies of NCBS-SH and DepEd Orders \\
\hline 3. & Reading SBM Principles, NCBS-SH and Kto12 Curriculum \\
\hline 4. & Relating questions to responsibilities and accountabilities of the school head. \\
\hline 5. & Finding the questions long, not clearly printed and difficult. \\
\hline 6. & Having difficulty analyzing and choosing the correct answer from the plausible choices. \\
\hline 7. & Having difficulty understanding the questions with difficult words. \\
\hline
\end{tabular}

Through careful comparison of the codes, those that have similar attributes or conceptually related were again grouped and categorized. As a result, the 51 categories were reduced to 13 , the sample of this categorization is shown in Table 3. 
Table 3. Related Properties and Conceptual Categories

\begin{tabular}{|c|c|c|}
\hline & Properties & Categories \\
\hline 1. & Having faith in God & \multirow{4}{*}{$\begin{array}{l}\text { 1. Trusting in the goodness } \\
\text { of God }\end{array}$} \\
\hline 2. & Believing in God and having faith in Him. & \\
\hline 3. & Praying to God & \\
\hline 4. & Praying to God for guidance & \\
\hline 5. & Studying the competencies of NCBS-SH and DepEd Orders & \multirow{7}{*}{ 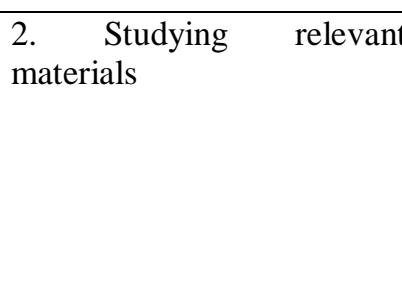 } \\
\hline 6. & Reading SBM Principles, NCBS-SH and Kto12 Curriculum & \\
\hline 7. & Having a self-review & \\
\hline 8. & Reading notes and relevant materials & \\
\hline 9. & Familiarizing with the competencies of the NCBS-SH & \\
\hline 10. & Reading DepEd Orders and other pertinent materials & \\
\hline 11. & Doing self-review & \\
\hline 12. & Developing good study habits & \multirow{7}{*}{$\begin{array}{l}\text { 3. Having the will and } \\
\text { determination to pass }\end{array}$} \\
\hline 13. & Feeling confident & \\
\hline 14. & Being free from stress & \\
\hline 15. & Being ready by reading materials & \\
\hline 16. & Attending review classes & \\
\hline 17. & Having the will and determination to pass the exam & \\
\hline 18. & Being emotionally, mentally and physically prepared & \\
\hline 19. & $\begin{array}{l}\text { Relating questions to responsibilities and accountabilities of the } \\
\text { school head. }\end{array}$ & \multirow[t]{5}{*}{$\begin{array}{l}\text { 4. Being familiar with the } \\
\text { tasks of the school head }\end{array}$} \\
\hline 20. & Answering questions pertaining to legal aspects of education & \\
\hline 21. & Relating work with NCBS-SH competencies & \\
\hline 22. & Being acquainted with the tasks. & \\
\hline 23. & Familiarizing with the tasks of the school head & \\
\hline 24. & Interpreting data and solving numerical problems & \multirow{5}{*}{$\begin{array}{l}\text { 5. Struggling with data } \\
\text { interpretation }\end{array}$} \\
\hline 25. & Answering questions pertaining to school management & \\
\hline 26. & $\begin{array}{l}\text { Replying to questions pertaining skills of school head in } \\
\text { establishing linkages }\end{array}$ & \\
\hline 27. & Analyzing situations that involved numerical data & \\
\hline 28. & $\begin{array}{l}\text { Finding difficulty on school operations, management, } \\
\text { supervision, community partnership and interpreting data }\end{array}$ & \\
\hline 29. & Having little or no knowledge on the issuances of the department & \multirow{4}{*}{$\begin{array}{l}\text { 6. Being complacent in } \\
\text { performing tasks }\end{array}$} \\
\hline 30. & Being dependent on someone else to take the lead & \\
\hline 31. & Disregarding policies in favor of humanitarian reason. & \\
\hline 32. & Delegating responsibilities to the teachers & \\
\hline 33. & Finding the questions long, not clearly printed and difficult. & \multirow{5}{*}{$\begin{array}{l}\text { 7. Having difficulty in } \\
\text { understanding the questions }\end{array}$} \\
\hline 34. & $\begin{array}{l}\text { Having difficulty analyzing and choosing the correct answer from } \\
\text { the plausible choices. }\end{array}$ & \\
\hline & $\begin{array}{l}\text { Having difficulty understanding the questions with difficult } \\
\text { words. }\end{array}$ & \\
\hline 36. & $\begin{array}{l}\text { Finding questions pertaining to School Management and } \\
\text { Supervision difficult }\end{array}$ & \\
\hline 37. & Having difficulty understanding high level questions & \\
\hline 38. & Feeling troubled due to family and physical problems. & $\begin{array}{l}\text { 8. Experiencing emotional } \\
\text { and physical stress }\end{array}$ \\
\hline & Experiencing mental block & \multirow[t]{2}{*}{ 9. Experiencing test anxiety } \\
\hline 40. & Being nervous & \\
\hline
\end{tabular}




\begin{tabular}{|c|c|c|}
\hline \multicolumn{2}{|r|}{ Properties } & Categories \\
\hline 41. & Being worried & \\
\hline 42. & Feeling afraid & \\
\hline 43. & Feeling too much excitement & \\
\hline 44. & Being unable to concentrate & \\
\hline 45. & Being physically unwell & $\begin{array}{l}\text { 10. Experiencing physical } \\
\text { stress }\end{array}$ \\
\hline 46. & $\begin{array}{l}\text { Being unable to concentrate due to inadequate facilities of the } \\
\text { testing center }\end{array}$ & $\begin{array}{l}\text { 11. Being affected by the } \\
\text { testing environment }\end{array}$ \\
\hline 47. & Being distracted by the proctor & \\
\hline 48. & $\begin{array}{l}\text { Responding to situations that did not happen or haven't } \\
\text { experienced yet. }\end{array}$ & $\begin{array}{l}\text { 12. Applying management } \\
\text { concepts into practical }\end{array}$ \\
\hline 49. & Putting into practice learning gained from training programs & situations \\
\hline 50. & Putting into practice NCBS-SH competencies & \\
\hline 51. & Experiencing difficulty in finishing the exam & $\begin{array}{l}\text { 13. Having poor time } \\
\text { management }\end{array}$ \\
\hline
\end{tabular}

After the major categories were compared with each other and consolidated, the data now transcend from categories to conceptual and finally to factors (Saldaña 2010). As shown in Table 4, the 13 categories are consolidated into 8 factors.

Table 4. Conceptual Categories and Factors

\begin{tabular}{|c|c|c|}
\hline & Conceptual Categories & Factors \\
\hline 1. & Having the will and determination to pass & 1. Strong desire \\
\hline 2. & Applying management concepts into practical situations & \multirow{2}{*}{ 2. Ability } \\
\hline 3. & Experiencing difficulty in time management & \\
\hline 4. & Studying relevant materials & \multirow{3}{*}{ 3. Effort } \\
\hline 5. & Being familiar with the tasks of the school head & \\
\hline 6. & Being complacent in performing tasks & \\
\hline 7. & Trusting in the goodness of God & 4. Luck \\
\hline 8. & Struggling with data interpretation & \multirow{2}{*}{ 5. Task difficulty } \\
\hline 9. & Having difficulty in understanding the questions & \\
\hline 10. & Experiencing emotional and psychological stress & 6. Emotional state \\
\hline 11. & Experiencing test anxiety & 7. Mental state \\
\hline 12. & Experiencing physical stress & \multirow{2}{*}{ 8. Physical state } \\
\hline 13. & Being affected by the testing environment & \\
\hline
\end{tabular}

Strong desire relates to an individual's will and determination to accomplish set goals. It is an innate yearning, a motivation, and its absence can affect the performance of the test taker.

Ability reflects how an individual puts into practice the theories and learnings gained from schooling and training such as applying instructional supervision and management concepts into practical situations of the school.

Effort is concerned with the preparation an individual exerts to pass the test. This includes scheduling time for study, familiarizing with the tasks of the school head and attending review classes.

Luck in the context of this study means the belief and faith of an individual in God. It conveys his natural submission by putting his trust in the Divine Providence demonstrated by prayer and conviction (Weiner, 1985).

Task difficulty relates to the struggle of the respondents in answering the questions particularly in data interpretation and management concepts. It describes their difficulty in understanding the questions and in choosing the right answer from the plausible choices. 
Emotional state refers to the condition of the respondents' emotions when they took the test. It denotes their recently experienced troubles and problems which affected their performance.

Mental state is concerned with the test anxiety that the respondents experienced in taking the test. It includes mental block, nervousness, inability to concentrate and their worry whether they can pass the examination.

Physical state refers to the well-being of test taker and the condition of the testing environment which contributed to physical stress.

The eight factors that emerged in the thematic analysis of the qualitative data are grouped according to the framework of this study. Ability and effort are the two dominant factors to which achievement is attributed (Weiner, 1985). They are categorized as internal, and are unstable and controllable which means these internal factors can be improved through persistent hard work. Task difficulty is categorized as external and stable, and luck is considered external and unstable. Emotional, mental, and physical states are thought of to be internal factors, unstable and controllable. Strong desire is categorized as internal, stable and controllable.

\subsection{Quantitative Phase}

After the data gathered through interviews and focus group discussions in the first phase were analyzed, the author developed a survey instrument to gather more detailed data on the emerging factors that affect NQESH performance.

The researcher developed indicators for each of the emerging factors, namely: strong desire, ability, effort, luck, task difficulty, emotional state, physical state, and mental state using a Likert Scale in order to measure attitudes in a scientifically accepted and validated manner (McLeod, 2014). The scale consisted of statements or indicators which elicited answers to the questions in this study. The participants were asked to show their level of agreement or disagreement on a scale of 1 to 5, 1 for strongly disagreeing and 5 for strongly agreeing with the given statements.

The questionnaire has three parts. Part I elicits information about the demographic profile of the respondents such as marital status, age, sex, NQESH status, rating obtained, present position, management experience, number of management trainings attended, and educational attainment. Part II measures the respondents' levels of perception on the factors that affected the NQESH performance such as strong desire, ability, effort, luck, task difficulty, emotional state, physical state, and mental state. Part III draws out information about their perceived level of difficulty of the seven NCBS-SH domains which are the main contents of the test.

Table 5 presents the profile of the respondents according to sex, marital status, age, management experience, present position, educational attainment, number of management trainings, and the number of times the respondents failed in the examination.

Table 5. Profile of the Respondents

\begin{tabular}{|c|c|c|}
\hline Basis & Frequency & Percent \\
\hline \multicolumn{3}{|l|}{ Sex } \\
\hline Male & 41 & 44.6 \\
\hline Female & 51 & 55.4 \\
\hline \multicolumn{3}{|l|}{ Marital Status } \\
\hline Single & 11 & 12.0 \\
\hline Married & 81 & 84.8 \\
\hline \multicolumn{3}{|l|}{ Age } \\
\hline $20-29$ & 13 & 14.1 \\
\hline $30-39$ & 23 & 25.0 \\
\hline $40-49$ & 36 & 39.1 \\
\hline $50-59$ & 20 & 21.7 \\
\hline \multicolumn{3}{|l|}{ Management Experience } \\
\hline $1-3$ years & 41 & 44.6 \\
\hline 4 years and above & 51 & 55.4 \\
\hline
\end{tabular}




\begin{tabular}{ccc}
\hline Basis & Frequency & Percent \\
\hline Present Position & 15 & 16.3 \\
Teacher III & 5 & 5.4 \\
Master Teacher & 39 & 42.4 \\
Head Teacher & 33 & 35.9 \\
Principal & & \\
Educational Attainment & 7 & 7.6 \\
With MA Units & 28 & 30.4 \\
MA (CAR) & 24 & 26.1 \\
MA & 16 & 17.4 \\
With Doctoral Units & 10 & 10.9 \\
Doctoral (CAR) & 7 & 7.6 \\
Doctoral & & \\
Level of Management Training & 60 & 65.2 \\
Divisional & 65 & 70.7 \\
Regional & 36 & 39.1 \\
National & 51 & 55.4 \\
International & & \\
Number of times failed in the examination & 6 & 6.5 \\
0 & 39 & 42.4 \\
1 times & 47 & 51.1 \\
\hline
\end{tabular}

\subsection{Profile of the Respondents}

Sex. More than half or $51(55.4 \%)$ of the respondents were female while $41(44.6 \%)$ were male. This supports the notion that the field of education is a female-dominated career.

Marital status. Out of 92 respondents, $81(84.8 \%)$ were married and $11(12 \%)$ were single. It suggests that the greatest number of the respondents performed dual responsibilities - in the school where they are assigned and in their respective families.

Age. The larger number of the respondents aged 40-59, comprising 56\% of the population while the remaining $36 \%$ aged 21-39. It can be surmised that majority of them who are in their prime age may reasonably demonstrate the characteristics of a responsible school head.

Management experience. Forty-one (44.57\%) respondents held a supervisory position for one to three years while 51 $(55.43 \%)$ held the supervisory capacity for four years and above. It implies that the larger population of the respondents had adequate experience in managing the school.

Present position. There were $20(21.74 \%)$ of the respondents who still had a teaching position, namely teacher III and master teacher, while $72(78.26 \%)$ of the respondents were already in the teaching-related position such as head teachers and school principals. It implies that not all schools in the $1^{\text {st }}$ Congressional District of Zamboanga Sibugay were handled by school heads whose item positions were already in the teaching-related plantilla.

Educational attainment. More than half, $59(64.13 \%)$ of the respondents had units or had earned a masteral degree while 33 ( $35.87 \%$ ) had units or had a doctoral degree. This indicates that all of the respondents in this study had graduate or post graduate studies which show that they were dynamic in their professional growth and development.

Level of management training. The data showed that divisional and regional levels had the most attendance (65 or 70.7\%) among the four levels of management training. This is due to the compulsory management training a school head must attend within a period of five years. It can be noted that the national level of management training had the least attendance comprising only $36(39.1 \%)$ respondents. This is because of the limited slots given to each division 
office and the selection of participants is the prerogative of the Schools Division Superintendent. The data further reveal that there were 51 (55.4\%) respondents who had attended the international level. This level is non-compulsory, voluntary, and very expensive in nature. Anyone can attend provided they pay for the registration fees and other expenses. Although this level of training is very costly, yet many school heads managed to attend because it has the highest equivalent points during the rating of performance appraisal and in the ranking for promotions.

Number of times failed in the examination. There were 47 (51.09\%) who failed in the examination for four times or more while $39(42.39 \%)$ failed once to three times. Only $6(6.52 \%)$ passed the examination right away. It suggests that only very few passed at their first attempt while the majority have failed many times in the NQESH.

\subsection{Emerging Factors}

The details of the emerging factors that were identified in the qualitative phase are presented herein by delving into the respondents' levels of perception of each factor.

Ability. Every school head is expected to perform exemplarily the competencies enumerated in the NCBSSH in order to help learners acquire skills that the $21^{\text {st }}$ century demands. Table 6 shows the participants' level of perception on their ability to implement these competencies.

Table 6. School Heads' (SHs) Levels of Perception on their Ability to Implement NCBS-SH Competencies

\begin{tabular}{|c|c|c|}
\hline Indicators & Wtd. $\bar{x}$ & Interpretation \\
\hline $\begin{array}{l}\text { 1. I allocated funds for maintenance of school facilities and } \\
\text { equipment. }\end{array}$ & 4.53 & Very High \\
\hline $\begin{array}{l}\text { 2. I conducted instructional supervision based on the supervisory } \\
\text { plan. }\end{array}$ & 4.39 & Very High \\
\hline $\begin{array}{l}\text { 3. I conducted dialogues and meetings with multi-stakeholders in } \\
\text { crafting programs and projects }\end{array}$ & 4.36 & Very High \\
\hline $\begin{array}{l}\text { 4. I organized programs for continuing personal and professional } \\
\text { advancement. }\end{array}$ & 4.23 & Very High \\
\hline $\begin{array}{l}\text { 5. I took the lead in providing learners an environment that promotes } \\
\text { the positive use of technology. }\end{array}$ & 4.16 & High \\
\hline $\begin{array}{l}\text { 6. I introduced research-based innovations in the school program to } \\
\text { achieve higher learning outcomes. }\end{array}$ & 4.12 & High \\
\hline $\begin{array}{l}\text { 7. I conducted needs assessment to teachers before the school year } \\
\text { starts. }\end{array}$ & 3.98 & High \\
\hline Average Wtd. $\bar{x}$ & 4.25 & Very High \\
\hline
\end{tabular}

The data show that of the seven competencies, four were perceived as very high while three were perceived as high. Furthermore, it unexpectedly revealed that financial management has the highest weighted mean instead of instructional supervision which is the primary concern of the school head. This is due to the fact that elementary school heads handle both financial management and instructional supervision. Due to the voluminous administrative tasks that the school head needs to perform, the weight of the burden shifted from instructional supervision to fiscal management as shared by the respondents.

The respondents also had very high level of perception on establishing strong linkages with stakeholders through constant and regular meetings, dialogues and fora to disseminate information on the success and challenges of the school as mandated by RA 9155. They also had very high level of perception in their ability to organize programs for continuing personal and professional advancement of teachers and staff. The respondents shared that they implemented this through Learning Action Cell (LAC) sessions, attendance in relevant trainings and enrolment in graduate studies. 
The data also reveal that the participants had high level of perception on their ability to provide learners an environment that promotes the positive use of technology. The Results-based Performance Management System (RPMS) require that Information and Communications Technology (ICT) should be utilized in curriculum delivery. The school heads are yet in the beginning stage of providing ICT equipment in each classroom of their respective schools due to limited resources.

In addition, the participants perceived the level of their ability in introducing research-based innovations as high. This perception is associated with the objective of DepEd Order 24, s. 2010, known as Basic Education Research Fund (BERF), which is to finance the conduct of education-related research. It categorized research into four themes such as teaching and learning, child protection, human resource development, and governance. DepEd encourages teachers and school heads to conduct research on these themes and utilize the recommendations in their respective classes, schools, districts and or division. In fact, respondents attested that research-based innovations in their respective schools whether in the delivery of the lesson or in other themes are in progress.

Participants perceived their ability to conduct needs assessment of the teachers high because it is one of the requisites in rating the Individual Performance and Commitment Review Form (IPCRF) of teachers. The participants shared that they conduct needs analysis of teachers in the month of May as basis for the LAC sessions and INSETs during semestral break. Although the competencies are equally important, they vary in frequency. Those that are perceived to be very high are performed monthly while those that are perceived to be high are performed at the beginning of the school year only.

Finally, the respondents of this study perceived their ability to implement the domains of the NCHS-SH as very high because of the management training afforded to them by DepEd through the National Educators Academy of the Philippines (NEAP) and other related trainings they participated. This affirmed the idea that training and ability have very favorable outcomes in terms of responsibility and performance of employees as Otuko et al. (2013) stated that training is basically essential to every employee and that it has a great influence in the achievement of the goals of an organization as a whole and to the individual in particular. This finding is strengthened by Weiner (1985) who said that ability, although internal, can be affected by circumstances and can be controlled through constant training, practice and determination of an individual to improve his aptitude to reach desired goals.

Strong desire. It refers to the innate motivating drive of the respondents in achieving their desired goal to pass the NQUESH. Table 7 presents the participants' perception on their strong desire to pass the NQESH.

Table 7. SHs' Levels of Perception on their Strong Desire to Pass the NQESH

\begin{tabular}{llcc}
\hline \multicolumn{1}{c}{ Indicators } & Wtd. $\bar{x}$ & Interpretation \\
\hline 1. I have the will and determination to pass the examination. & 4.48 & Very High \\
2. I see myself as a successful school principal. & 4.24 & Very High \\
3. I want to lead a school to be recognized for my ability. & 4.16 & High \\
4. I was encouraged by my family. & 4.14 & High \\
5. I envy those who already passed the test and had become & 3.08 & Average \\
$\quad$ successful school principals. & & \\
\hline Average Wtd. $\bar{x}$ & 4.06 & High \\
\hline
\end{tabular}

Table 7 show that the respondents had very high level of perception on their determination to pass and to see their selves as successful principals. This reflects a very high innate motivation. As a matter of fact, a participant said that his determination did not wane even when he failed twice in the examination while another said that she kept on seeing herself as one of the successful school principals. These statements are affirmed by the finding of Manik and Sidharta (2017) that motivation contributes to a worker's very high determination to succeed in an organization.

Recognition for an outstanding performance is akin to graduating from college with flying colors. Participants of this study had a high perception on being recognized for their exemplary performance in the school. Kelley et al. (2000) stated that when a school administrator is recognized for his performance, greater value will be placed on the learning outcomes that would lead to more effort and sustained high performance of the school head. 
Awards and recognition given to teachers and school heads who demonstrate high commitment, exemplary competence and remarkable dedication to their work are now the mandate of the DepEd Secretary. This is to acknowledge the crucial role, loyal service, and faithful commitment of both school heads and teachers in developing globally-competitive citizens (Flora 2019). During the FGD, a participant envisioned that her school will be recognized for its accomplishments, bringing honor to her as the school head and to the school community as stake holders.

The level of family encouragement was perceived as high because, as Filipinos, we have close family ties and that we value our family above all others. This is supported by Haykal (2015) who found that family is the individual's first learning environment and the vital support that contributes to success in achieving goals.

Table 7 shows that the average level of envy to others who passed the test implies that some participants were not very envious to those who already passed the NQESH in the full sense of the word. Instead, they regarded them as their inspiration, their mentors, and as their role models as shared by the participants during the FGD. These insights strongly support the statement that inspiration awakens an individual to new possibilities by allowing himself to transcend his ordinary experiences and limitations, making that person propel from apathy to possibility and eventually transform the way he perceives his own capabilities. It helped facilitate advancement towards set goals and objectives. An individual who is inspired in his daily life tends to set goals which can be successfully attained (Kaufman, 2011).

However, one participant admitted that he had a little bit of that feeling but did not compare himself with those who already passed the exam because of individual differences. Another also pointed out that envy would tend to compare his ability with the others which will certainly have a negative effect on himself. These statements are supported by Morin (2017) who found that envy is a normal emotion that everyone experiences in an organization. However, this feeling can grow into resentment and bitterness if not controlled by the affected individual. To avoid this pitfall, one should stop comparing himself with others and continue to tread on the path of his career honoring individuality and diversity.

Effort. This factor refers to the preparation done by the respondents before taking the examination which involves study schedule, application of theory-to-practice, and time management.

Presented in Table 8 are the perceived levels of the respondents' effort in preparing themselves for the NQESH.

Table 8. SHs' Levels of Perception on their Effort to Pass NQESH

\begin{tabular}{llcc}
\hline Indicators & Wtd. $\bar{x}$ & Interpretation \\
\hline 1. I applied into practice the learnings gained from training & 3.98 & High \\
$\quad$ programs & 3.92 & High \\
2. I had a self-review on DepEd issuances, NCBS-SH, SBM and & & \\
$\quad$ other relevant materials as the examination was approaching. & 3.18 & Average \\
3. I set aside a time every day to practice test materials. & 2.75 & Average \\
4. I joined group studies with my colleagues. & 2.54 & Low \\
5. I attended review classes all the time. & 3.41 & High \\
\hline Average Wtd. $\bar{x}$ & &
\end{tabular}

The participants had a high level of perception in applying their learnings from trainings to address management and supervisory issues in their respective schools. The participants shared that they put into practice the learnings they gained from trainings because this is the core principle of Authority, Responsibility and Accountability (AURA) of school heads cited in RA 9155.

The data also reveal that the respondents admitted that they had self-review only when the examination was fast approaching. The respondents explained that this was due to the nature of their job to multi-task in order to meet the required ends that the NCBS-SH obliged them to do.

Table 8 also reveals that the participants were not so conscientious in setting time to practice the test materials and in having group studies. The participants disclosed that they were physically and mentally exhausted at the end of the 
day and that they also had to attend to the needs of their own families during the week-ends. Nevertheless, they admitted that they read test materials when they had spare time which was very seldom, indeed. They added that they were always running-out of time.

When asked about group studies, the participants claimed that only those who were at a proximal distance made it, but not on a regular schedule. The respondents divulged that they basically lacked commitment for group study and the skill in managing their time wisely. This inadequate effort is supported by the findings of Silm et al. (2013) that test results were influenced by covariate variables such as test-taking effort, and test-taking patterns. Furthermore, Pattaguan (2016) attested that one of the best practices to pass an examination was the use of study groups which helped students review their lessons and eventually helped them organize review sessions in preparation for board examinations. Similarly, Holloway (2001) concluded that special grouping arrangements, such as peer tutoring and group review sessions can bring about an increased student learning and a higher possibility of success.

Table 8 further reveals that there was low attendance in review classes because there is no review center that offers NQESH review in the nearby cities like Pagadian or Zamboanga. Review centers are in Cagayan de Oro City and the respondents shared that distance and work load were the constraints that prevented them from enrolling in these review classes.

As a whole, the average weighted mean (3.41) shows that the participants' level of perception in their effort to pass the test is high. This is noteworthy since Weiner (1985) stated that effort is one of the factors that an individual attributes his achievement-related undertakings.

Luck. This refers to the respondents' reliance on the Divine Providence. Table 9 presents their perceptions on luck which in the context of this study is their belief on the help from the Almighty.

Table 9. SHs' Levels of Perception on Luck

\begin{tabular}{lcc}
\hline Indicators & Wtd. $\bar{x}$ & Interpretation \\
\hline 1. I believe that God sees what is best for me. & 4.89 & Very High \\
2. I prayed to God to guide me in answering the test questions. & 4.87 & Very High \\
3. I asked God for his blessing in taking the examination. & 4.86 & Very High \\
4. I believed that there are things that happen in my life which are & 4.84 & Very High \\
$\quad$ beyond my control. & 4.59 & Very High \\
5. I left everything to God & 4.57 & Very High \\
\hline Average Wtd. $\bar{x}$ & &
\end{tabular}

The data remarkably reveal that the respondents had a very high level of perception on luck. The majority of the respondents $81(88 \%)$ were Christians while only $11(12 \%)$ were Muslims. Despite diverse religious points of view, principles and beliefs, the concept and interpretation of luck as an attribute of God's favor towards his creations was universally recognized by the respondents. Those who passed the examination attributed their success to God, while those who did not still ascribed to God's will.

During the encoding of the data, the researcher found that those who passed the examination ticked all the boxes in the highest level (5) while those non-passers ticked mostly the second next highest level (4) and few ticked the average (3). This explains the very high weighted mean, affirming the conclusion of Rescher (1995) that as far as the individual is concerned, the positive result of an event came about by the will of the Creator.

Among the factors explored in this study, luck has the highest average weighted mean, implying that the participants had strong belief in God as the master designer of their fate. Weiner (1985) said that luck is one of the dominant factors in the causality of achievement-related contexts. He added that an individual might perceive luck as an external and unstable cause of his success, unstable because at first try he was not successful, only on the second or third try when the stability of luck changed. Others conceived it as an enduring personal property, which had made that affected individual successful in most of his intentions.

Task difficulty. Task difficulty, in the context of this study, is concerned with the participants' difficulty in answering the test. Their perceived points of view on the level of difficulty of the test are presented in Table 10. 
Table 10. SHs' Levels of Perception on Task Difficulty

\begin{tabular}{lcc}
\hline Indicators & Wtd. $\bar{x}$ & Interpretation \\
\hline 1. I experienced difficulty in choosing the correct answer from the & 3.85 & High \\
$\quad$ plausible choices & 3.60 & High \\
2. I had difficulty in interpreting graphs and tables. & 3.55 & High \\
3. I found analyzing situations that involved numerical data very & 3.54 & High \\
$\quad$ hard. & 3.26 & Average \\
4. I experienced difficulty in understanding the questions. & 3.73 & High \\
5. I experienced difficulty in finishing the exam. & \\
\hline Average Wtd. $\bar{x}$ &
\end{tabular}

The data show that the participants' level of perception on the first four indicators is high. This means that the test was difficult for them. This can be attributed to their critical thinking skills, mathematical skills, and analytical skills. Interpreting graphs and tables and analyzing situations involving numerical data would be difficult for one who does not have adequate mathematical skills. In addition, analytical skill is needed since the examination consists of situational critical thinking questions pertinent to the functions of school heads as defined in the NCBS-SH Domains (D.O. 32, 2010). The respondents recounted that aside from the difficulty in understanding what the questions meant, it was difficult to identify the correct answer since the choices seemed to be all correct.

The data further reveal that the participants' level of perception in finishing the exam is average. It denotes that the test takers did not experience a hard time in finishing the examination and finished it within the allotted time as revealed by the participants during the FGD. Additionally, one participant stressed that since time is beyond their control, one should have a system in answering the answers like skipping the items that were too hard to comprehend and moving to the next items, and that while it is true that test takers have no control over the time allotted for the exam, at least they can control the way they answer the test.

The overall weighted mean which is $\mathbf{3 . 7 3}$ (high) reveals that the respondents experienced high level of difficulty in answering the test. In relation to this, Weiner (1985) who stated that task difficulty is external and stable, which means that the individual has no control over it.

Emotional state. This factor probes on their feelings before, during, and after taking the test. Table 11 presents the respondents' levels of perception on their emotional state.

Table 11. SHs' Level of Perception on their Emotional State

\begin{tabular}{lcc}
\hline Indicators & Wtd. $\bar{x}$ & Interpretation \\
\hline 1. I had a positive feeling when I took the test. & 4.18 & High \\
2. I felt encouraged that the questions were related to my readings. & 3.84 & High \\
3. I was satisfied with my answers in most of the questions. & 3.82 & High \\
4. I had problems before I took the test. & 3.53 & High \\
5. I was worried that I cannot pass the test at the time I took it. & 3.26 & Average \\
6. I felt discouraged because the questions were too difficult for me to & 3.23 & Average \\
$\quad$ answer when I read them. & & High \\
\hline Average Wtd. $\bar{x}$ & 3.64 &
\end{tabular}

The data reveal that the respondents had a high positive feeling when they took the test since the questions were related to their readings. Hence they were satisfied with their answers in most of the questions. They were emotionally conditioned, prepared and worry-free that they were able to focus on the test as shared by the respondents. However, some participants had problems before they took the examination. One of the respondents recounted that she was bothered because her husband was very irritable and could hardly manage their young children. He was in the initial process of stopping the use of an illegal drug (shabu). Others shared that they were not able to focus on the examination because of their problems. Silm et al. (2013) explained that persons who cannot control their emotions especially in responding to problems and stress-related situations have difficulty in concentrating while taking the test. 
The data also reveal that the participants were not too optimistic in passing the examination due to the difficulty of the questions. In addition to their inadequate preparation, this could be due to family problems such as financial matters, education of their children, relationship with their spouses and family feuds, work-related problems such as relationship of teachers and community, backlogged administrative reports and fiscal matters of the school. A participant pointed out that while she was answering the test, she also began to worry about not passing the test because of the problems she had at home and in her workplace. Another also shared that as he went on answering the test items, his interest waned and was replaced by worrying about failing because of the difficult questions. One even said that she cried out of frustration on her way home.

These experiences are confirmed by the findings of Olarinan (2013) who acknowledged that situations which constitute emotional and psychological problems like money worries, family and work-related problems can cause failure in examination. The inability of the test takers to interpret and understand the questions also have a significant effect on their performance.

Physical state. This factor relates to the well-being of an individual and the condition of the testing environment which contributed to physical stress.

Table 12 reveals the levels of perception of school heads on their physical condition during the examination.

Table 12. SHs' Levels of Perception on their Physical State

\begin{tabular}{llcc}
\hline Indicators & Wtd. $\bar{x}$ & Interpretation \\
\hline 1. I was in good physical condition when I took the test. & 4.03 & High \\
2. I was not feeling well when I took the examination & 4.00 & High \\
3. I experienced discomfort while taking the examination. & 3.95 & High \\
4. I was not comfortable with the facilities of the venue. & 3.91 & High \\
\hline Average Wtd. $\bar{x}$ & 3.79 & High \\
\hline
\end{tabular}

The data reveal that the respondents had high level of perception on their physical condition when they took the test as also revealed during the FGD. Some of them said that they were at the venue a day or two before the examination to avoid exhaustion from travelling and did nothing that can hinder their relaxation. Others mentioned that they even had a body treatment from health spas.

However, the data show that some of the participants were not feeling well when they took the examination. This resulted from lack of sleep due to their travel and illnesses. Others also attributed their discomfort to the testing facilities such as distance of the comfort rooms, lighting and ventilation, and seating facilities. These statements are supported by Singh et al. (2016) who found that there is a positive and statistically significant impact of learning facilities to student performance. Similarly, the study of Quiambao et al. (2015) reported that testing facilities was a very significant predictor in passing the licensure examination. Moreover, Olarinan (2013) stated that physical problems can prevent a test taker from concentrating on the test items and thereby affect performance. This can happen when an individual has inadequate sleep or rest, fatigue, sickness like respiratory infections and other diseases which hinder the mental faculty to process information correctly and think critically.

Mental state. In the perspective of this study, this factor refers to the level of psychological readiness and test anxiety experienced by the respondents.. Table 13 presents the levels of perceptions of the participants on their mental state when they took the test.

Table 13. SHs' Levels of Perceptions on their Mental State

\begin{tabular}{llcc}
\hline Indicators & Wtd. $\bar{x}$ & Interpretation \\
\hline 1. I had a positive mind-set when I took the examination. & 4.13 & High \\
2. I experienced spontaneous recollection of information during the & 3.50 & High \\
$\quad$ examination. & & \\
3. I was not able to concentrate on the test questions. & 3.50 & High \\
4. I suddenly felt nervous when I received the test booklet. & 3.47 & High \\
5. I experienced mental block when I started reading the questions. & 3.43 & High \\
\hline
\end{tabular}




\begin{tabular}{lccc}
\hline Indicators & Wtd. $\bar{x}$ & Interpretation \\
\hline Average Wtd. $\bar{x}$ & 3.64 & High \\
\hline
\end{tabular}

The data show that the participants had high levels of perceptions on their positive mind-set and in their spontaneous recollection of information. These perceptions are the products of their mental preparation through thinking positively of the outcomes and avoiding cognitive overload such as reading materials even at the very day of the examination. A participant emphasized that the only thing one should do to remember is to forget, which implies to forget about the examination and free the mind from doubts and reservations so that the mental faculty can easily retrieve information during the exam. Another participant distinctly said that being optimistic by accepting any outcome of the test can give a peace of mind.

Table 13 further indicates that the participants had also experienced high level of difficulty in concentration, nervousness, and mental block. These were the tensions that built-up as by-products of their anxiety about their performance in the examination, their constant and unrelenting apprehension about their ratings, restlessness, and over-burden of the mind as explained by Carr (2016). Those who experienced test anxiety performed poorly in the examinations because it contributed challenges to information processing of the mind especially during evaluative situations. In addition, Yusefzadeh et al. (2017) pointed out that those who suffer from test anxiety can experience distraction in preparing for the test and more so during the actual examination.

NCBS-SH domains. This factor draws out information about the perceived level of difficulty of the test items in the seven domains of NCBS-SH. Table 14 presents the participants' levels of perceptions on the difficulty in each of the NCBS-SH domains.

Table 14. SHs' Levels of Perception on the Difficulty of NCBS-SH Domains

\begin{tabular}{llrc}
\hline Indicators & Wtd. $\bar{x}$ & Interpretation \\
\hline 1. & Instructional leadership & 3.37 & Average \\
2. $\quad$ School leadership & 3.36 & Average \\
3. School management and operations & 3.32 & Average \\
4. $\quad$ HR management and professional development & 3.24 & Average \\
5. $\quad$ Creating a student-centered learning climate & 3.22 & Average \\
$6 . \quad$ Personal and professional attributes & 3.09 & Average \\
$7 . \quad$ Parent involvement and community partnership & 2.98 & Average \\
\hline Average Wtd. $\bar{x}$ & 3.22 & Average \\
\hline
\end{tabular}

The data indicate that the participants have average levels of perception on the difficulty of the test items which suggests that they perceived the questions as neither difficult nor easy. This can be attributed to the recently concluded School Heads' Development Program (SHDP) that gave focus on the NCBS-SH domains as DepEd's response on the alarming very low examination rating of the school heads in the NQESH.

Table 14 shows that instructional leadership is perceived as the most difficult area in the examination followed by school leadership. This is due to the way the questions were constructed that required critical and analytical thinking skills. Moreover, the respondents shared during the FGD that they needed to read the questions more than once to understand them clearly. Others also shared that the questions can cause confusion if they have not mastered the competencies of the NCBS-SH. These statements are affirmed by the finding of Ceralde (2014) who attested that the examination is composed of situational critical thinking questions which pertained to the roles of school head as a multi-faceted individual who performs the duties and responsibilities prescribed by the NCBH-SH.

The data further reveal that parent involvement and community partnership has the lowest weighted mean of $\mathbf{2 . 9 8}$ (average) and was perceived as the easiest among the areas of the exam. This notion is due to the fact that this practice had been the tradition of the Philippine Educational System since its establishment (Cuevas, 2016). The respondents shared that they had been establishing linkages with the parents and the community years before the NCBH-SH was institutionalized in DepEd. 
Table 14 also shows that the overall perceived level of difficulty of the questions is average. Although the questions were perceived to be at an average level of difficulty, yet most of those who took the test failed because of other factors that affect their performance such as text anxiety, plausible options, inability to think critically, mental, emotional, and physical state.

\subsection{Relationship of Factors and NQESH Performance.}

To find out the relationship between the factors and NQESH performance, Pearson-Product-Moment Correlation (Pearson $\mathrm{r}$ ) was used. The $r$ and $p$ values of these factors are presented in Table 15.

Table 15. Correlation Coefficients between Levels of Perceptions of Emerging Factors and the NQESH Performance

\begin{tabular}{llccc}
\hline Factors & $r$-value & $p$-value* & Verbal Interpretation \\
\hline 1. & Ability & .245 & .018 & Significant \\
2. & Luck & .231 & .026 & Significant \\
3. & Effort & .231 & .027 & Significant \\
4. & Task difficulty & -.223 & .032 & Significant \\
5. & Physical state & -.215 & .040 & Significant \\
6. & NCBS-SH Domains & -.211 & .044 & Significant \\
7. & Emotional state & -.180 & .086 & Not Significant \\
8. & Mental state & -.154 & .144 & Not Significant \\
9. & Strong desire & .063 & .552 & Not Significant \\
\hline
\end{tabular}

Table 15 shows that out of nine emerging factors, six factors, namely: ability, luck, effort, task difficulty, physical state, and difficulty of questions on NCBS-SH domains have significant relationship with NQESH performance. The three factors, namely: emotional state, mental state, and strong desire have no significant relationship with NQESH performance.

Ability. There is a significant relationship between NQESH performance and ability at $r=.245, p=.018$. The higher one's ability, the higher is his performance in the test. This interpretation is supported by the statements of the respondents that applying their abilities learned from their undergraduate and graduate courses and trainings into practical situations in the school had a positive effect in taking the test. Ceralde (2014) upheld that trainings can develop the managerial and supervisory abilities of aspiring school principals by putting their learned theories into practical applications in the school.

Luck. There is also a significant relationship between NQESH performance and luck at $r=.231, p=.026$, which means that the more they put their trust in God, the higher is their performance in the test.? This reflects the participants' strong belief in the Divine Providence and their unwavering faith in God. This is further validated by the theory of Weiner (1985) that luck is one of the key factors which people attribute their achievements to.

Effort. There is a significant relationship between NQESH performance and effort at $r=.231, p=.027$. This means that those who exerted more effort in preparing themselves for the examination had a favorable result than those who did not. This finding is reinforced by Sobotka (2017) who disclosed that effort exerted had helped the respondents achieve passing scores on licensure examinations. In addition, Tan (2014) also found that effort in terms of study habits was significantly related to the performance of test takers.

Task difficulty. There is a negative correlation between NQESH performance and task difficulty at $r=$ $.223, p=.032$. This means that the lower the difficulty of the examination questions, the higher is the performance in the test. This interpretation is corroborated by Visco (2015) who reported that test difficulty had a significant influence on test results. Similarly Sadiq, et al. (2017) revealed that that the conduct of the examination, technical errors and the level of difficulty of the questions had significant influence on the test result in board examinations. In fact, Refugio (2017) suggested that an intensive review program should be undertaken because of the difficulty of the examination. 
Physical state. There is also a negative correlation between NQESH performance and physical state at $r=$ $.215, p=.040$ which suggests that the lower the test takers' physical stress level, the higher is their performance in the test. This interpretation is confirmed by some of the respondents who related that their failure was due to their physical condition at the time they took the examination.

NCBS-SH domains. There is a negative correlation between NQESH performance and the difficulty of the questions pertaining to the NCBS-SH domains at $r=-.211, p=.044$. It implies that the lower the difficulty of the questions, the higher is the performance of the test takers. This interpretation is supported by the respondents who shared during the FGD that they scored below the cut-off score of $70 \%$ in each clustered domain because of the level of difficulty of the questions.

However, the three factors that had no significant relationship with the respondent's performance in the NQESH are emotional state, mental state, and strong desire. Although those who were interviewed had perceived them to have an impact on their performance, such impact was not apparent in the majority of the respondents. It can be construed that these factors were not too intense to distract their focus or influence their performance in taking the test, hence, are found to be of no significance.

\subsection{Significant Difference in NQESH Performance based on the Participants' Profile.}

This study further sought to establish whether a significant difference in the NQESH performance of the respondents existed when grouped according to their profile variables. Table 16 presents the data that revealed the answer to this query using t-test.

Table 16. Significant Difference of NQESH Performance based on Profile Variables. (N=92)

\begin{tabular}{|c|c|c|c|c|c|}
\hline \multicolumn{2}{|c|}{ Variables } & \multirow{2}{*}{$\begin{array}{l}\text { Group } \\
\text { Masteral } \\
\text { Doctoral }\end{array}$} & \multirow{2}{*}{$\begin{array}{l}\begin{array}{l}\text { Mean } \\
(\bar{x})\end{array} \\
68.82 \\
77.66\end{array}$} & \multirow{2}{*}{$\frac{p \text {-value* }}{.017}$} & \multirow{2}{*}{$\begin{array}{l}\begin{array}{l}\text { Verbal } \\
\text { Interpretation }\end{array} \\
\text { Significant }\end{array}$} \\
\hline 1. & Highest Educational & & & & \\
\hline & $\begin{array}{l}\text { Attainment } \\
\text { Level of Management }\end{array}$ & $\begin{array}{l}\text { Doctoral } \\
\text { Division-Region }\end{array}$ & $\begin{array}{l}77.66 \\
6805\end{array}$ & & \\
\hline 2. & Training & Nat'l-International & 83.15 & .001 & Significant \\
\hline 3. & Marital Status & $\begin{array}{l}\text { single } \\
\text { married }\end{array}$ & $\begin{array}{l}80.13 \\
70.82\end{array}$ & .046 & Significant \\
\hline 4. & Number of times failed & $\begin{array}{l}0-3 \text { times } \\
4 \text { times above }\end{array}$ & $\begin{array}{l}74.69 \\
69.41\end{array}$ & .158 & Not Significant \\
\hline 5. & Present Position & $\begin{array}{l}\text { Teachers } \\
\text { Administrators }\end{array}$ & $\begin{array}{l}67.42 \\
73.18\end{array}$ & .175 & Not Significant \\
\hline 6. & Management Experience & $\begin{array}{l}1-3 \text { years } \\
4 \text { year } \& \text { above }\end{array}$ & $\begin{array}{l}73.70 \\
69.67\end{array}$ & .275 & Not Significant \\
\hline 7. & Sex & $\begin{array}{l}\text { male } \\
\text { female }\end{array}$ & $\begin{array}{l}72.95 \\
71.24\end{array}$ & .657 & Not Significant \\
\hline 8. & Age & $\begin{array}{l}21-39 \\
40-55\end{array}$ & $\begin{array}{l}72.41 \\
71.85\end{array}$ & .898 & Not Significant \\
\hline
\end{tabular}

* - at 0.05 level of significance

It is worth noting that the respondents significantly differ in their NQESH performance based on highest educational attainment, level of management training, and marital status.

Table 16 shows that when respondents are grouped according to highest educational attainment, those who had doctoral units or a doctoral degree performed better that those who only had masteral units or a master's degree. A higher degree provides more comprehensive knowledge on school management, more hands-on educational practices and more opportunities to apply foundational knowledge to real world organizational leadership. 
When the respondents are grouped according to their level of management training, a significant difference can be observed. A relatively larger number of passers, with a mean of 83.15, had attended national and international levels of management training as compared to those who did not pass the test. This can be attributed to the type of training approaches employed to guide the participants in relating educational management and instructional supervision concepts to practical applications in the school and in improving their managerial and leadership skills. These levels of training also give extra focus on the challenges that DepEd is currently confronting such as quality of education, provision of educational facilities, fiscal management, and linkages which are generally related to the questions of the NQESH.

The data suggest that the level of management training can impact significantly on the performance of the test takers. Galiza et al. (2018) explained that trainings can significantly relate to the performance of the test takers. Additionally, Gorjup et al. (2009) found that training can affect the performance and promotions-related undertakings of an employee.

The data further reveal that, when grouped according to marital status, the single respondents performed better than the married respondents. It means that individuals with no family responsibilities had a more focused mind-set while taking the test than married individuals because they tend to bear troubles about their responsibilities of their families (Griffiths et al., 2004) and family-related problem like financial matters (Al-Zoubi \& Younes, 2015).

It can be remarkably noted that there is no significant difference in the performance of the NQESH when grouped based on present position, sex, number of times failed, management experience, and age. This means that these variables do not contribute a significant difference in the NQESH performance.

\subsection{Proposed Model}

This study also sought to propose a model that can help the school heads improve their performance in taking the NQESH. The researcher employed stepwise regression as it includes only significant predictor variables which contribute uniquely to the outcome variable.

An analysis of standard residuals was carried out on the data to identify any outliers, which indicated that participants 7 and 12 needed to be removed. After removing participants 7and 12, an analysis of standard residuals was carried out once more which showed that the data contained no more outliers. The collinearity diagnostics was performed to test if the data met the assumption of collinearity. The result indicated that multicollinearity was not a concern. After these assumptions were satisfied, the stepwise regression analysis for the emerging factors and profile variables were conducted. The analysis yielded four models and the fourth showed a very high contribution in NQESH performance. The summary of the data of the said model is presented in Table 17.

Table 17. Regression Model Summary Table

\begin{tabular}{lccccc}
\hline Predictors & $\boldsymbol{R}$ & $\boldsymbol{R}^{\mathbf{2}}$ & $\boldsymbol{d f}$ & $\boldsymbol{F}$ & $\boldsymbol{p}$-value* \\
\hline NCBS-SH & .747 & .557 & 1,88 & 110.78 & .000 \\
Training & .773 & .598 & 2,87 & 64.61 & .002 \\
Ability & .788 & .621 & 3,86 & 46.99 & .016 \\
Task difficulty & .800 & .640 & 4,85 & 37.78 & .038 \\
\hline * - at 0.05 level of significance & & & & \\
Model 1 NCBS-SH & & & & \\
Model 2 NCBSH-SH+ training & & & \\
Model 3 NCBSH-SH + training +ability & & & \\
Model 4 NCBSH-SH+ training +ability+ task difficulty & & \\
Dependent Variable: NQESH Performance & & &
\end{tabular}

Table 17 shows the value of $\mathrm{R}^{2}$ which denotes the amount of variance that each predictor variable uniquely explains or accounts for in the outcome variable. The amount of variance that each predictor accounts for is statistically significant at $\mathrm{p}<0.05$. Only four variables are found to be predictors. The first model shows that NCBS-SH accounts 
for $55.70 \%$ of the variance of NQESH performance. The second model consisting of NCBS-SH and training explains $59.80 \%$, the third model which is composed of NCBS-SH, training, and ability contributes $62.10 \%$; while the fourth model consisting of NCBS-SH, training, ability, and task difficulty can explain $64.00 \%$ of the NSESH performance.

The model suggests that school heads should be well-acquainted with the NCBS-SH competencies and put them into practical application in managing the school and supervising instruction. They should also engage in professional development by attending management training, whether mandatory or optional, to enhance and keep abreast with the current trends of school management. It also reveals the importance of developing critical and analytical skills to arrive at the best possible answers to the questions at hand.

Moving automobile model. This model is adopted from the work of Baang (2010). It is found to be the most suitable model for this study as illustrated in Figure 3. It is modified to take into account the predictors identified in the two regression models. It also serves as the response to the recommendation of Ceralde (2014) who suggested that a similar study of his shall be done involving other predictors covering one or more years of NQESH results combined, with an increased breadth of respondents in order to find more significant variables which may have an influence on the test performance.

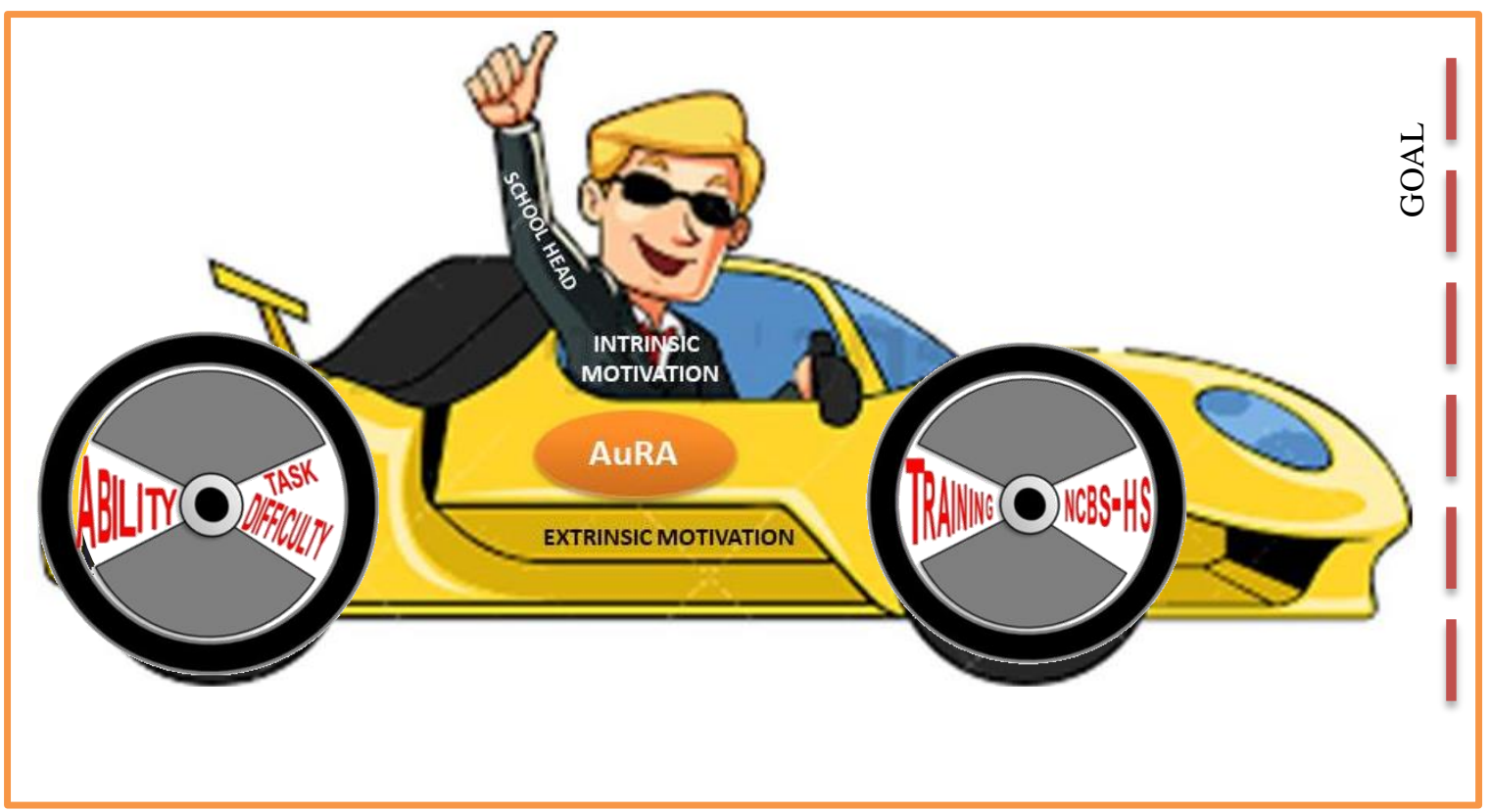

Figure 3. The Modified "Moving Automobile Model"

Photo source: https://www.123rf.com/photo_50969571_stock-vector-cartoon-illustration-of-a-mandriving-a-sports-car-.html

Figure 3 shows the school head onboard an automobile, which represents the Authority, Responsibility and Accountability (AuRA) of his being a school head as stipulated in R.A. 9155, his effort exerted to achieve his goal, and his motivations. The automobile AuRA is supported by two sets of tires which are reinforced by a couple of spokes that represent the predictor variables identified in the regression model namely: ability, task difficulty, level of management training, and NCBS-SH domains. The goal is the cut-off score of the NQESH which is at least $70 \%$ in each clustered NCBS-SH domains (D.M. 93, 2018).

The model is anchored on the goal-setting theory of Locke and Latham (1990) which hypothesized that individuals set challenging but attainable goals which are specific and measurable, and that the concerned individual must commit to the set goals in order for him to put sufficient effort towards reaching them. The setting of these goals involves 
extrinsic rewards and intrinsic motivation. Extrinsic reward in this case can be the recognition paired by increased salary ranging from $11 \%$ for master teacher to $79 \%$ for teacher 3 (Executive Order No. 201, s 2016).

By expanding the intrinsic motivation of Locke's (1990) goal-setting theory, the theory of Abraham Maslow's (1943) hierarchy of needs comes in, particularly esteem needs, and self-actualization. Esteem needs are concerned with the individual's need for acknowledgement from others, such as passing the examination and becoming a full-fledged school principal while self-actualization needs are the desire of an individual to achieve something that can be left behind as his legacy like outstanding accomplishments that are duly recognized by the higher offices (Saif et al., 2012).

Another theory upon which this model is built is that of McClelland's achievement motivation theory as it proposes that the needs or motives for achievement, affiliation, and power are influenced by either internal drivers or extrinsic factors. Internal drivers are actions that trigger the desire to achieve something which emanate from the psychological need for competence that is the striving effort for excellence, such as, in the context of this model, passing the examination and holding a school principal position. The external factors come from the individual's environment and socialization influences such as family support and encouragement, recognition and esteem which could trigger the pursuit to personal growth and professional development. Finally, this model is attributed to Self-Determination Theory (SDT) of Ryan and Deci (2000) which gives focus on the basic psychological needs of autonomy, competence, and relatedness. This theory rests on the concept that individuals are continuously involved in an active interaction with the society. This interaction is the product of intrinsic motivation which refers to pursuing of something because of its inherent stimulating and pleasing qualities or as an outcome of an extrinsic motivation which pertains to doing something because it leads to a very distinguished result. Autonomy refers to the need of individuals to feel free and self-directed, relatedness is concerned with the need of an individual to connect closely with others in order for such individual to grow, prosper and succeed while competence is the need to feel effective which causes the action of an individual to seek out the most favorable challenges and the development of human capacities.

\section{Conclusions}

Success or failure in an examination has its causal ascription to both internal and external factors. The internal locus of control factors such as ability, effort, physical state and NCBS-SH domains along with the external locus of control factors such as luck and task difficulty wield a significant influence on one's performance. Considering that there are more internal factors, success in examinations depends greatly on one's effort, determination, and persistent hard work. Individuals must assert to themselves that they, and no other, are mainly responsible for the success in any undertaking.

School heads should not only acquire a comprehensive theoretical understanding on the concepts of the NCBS-SH competencies but also on their practical applications in order for them to develop, improve and enhance their ability in school management. In addition, dynamic professional development and more developed critical and analytical skills are definitely needed to pass the NQESH.

\section{References}

Allaga, W. \& Pachejo S. (2011). Academic predictors of the licensure examination for teachers' performance of the Rizal Technological University teacher education graduates. International Journal of Educational Research and Technology, 4, 31-40. https://www.soeagra.com/ijert/ijert.htm

Al-Zoubi, S. \& Younes, M. (2015). Low academic achievement: Causes and results. Theory and Practice in Language Studies, 5(11), 2262-2268. https://doi.org/10.17507/tpls.0511.09

Ang, R., Gonzalez, M. C., Liwag, M. E., Santos, B., \& Yu, V. (2001). Elements of student-centered learning. Office of Research and Publications, Loyola Schools, Ateneo de Manila University. https://www.ateneo.edu/sites/default/files/Elements\%20of\%20Student\%20Centered\%20Learning_2012.pdf 
Baang, M. (2012). Investigating the macro perspective affecting the passing rate in board examinations: A take-off point in designing a causal model. International Journal of Learning, Teaching and Educational Research, (15) 4, 108-120. https://www.ijlter.org/index.php/ijlter/article/view/676/295

Baker-Doyle, K.J. \& Petchauer, E. (2015). Investigating teacher licensure exam advice networks. Teacher Education Quarterly, 3-32. https://doi.org/10.17583/remie.2015.1495

Brooks, J., \& Sutherland, I. (2014). Educational leadership in the Philippines: Principals' perspectives on problems and possibilities for change. Planning \& Changing: An Educational Leadership and Policy Journal, 45(3/4), 339-355. https://research.monash.edu/en/publications/educational-leadership-in-the-philippines-principalsperspectives

Canavan J., Dolan P. \& Pinkerton J., (2000). Family support: Direction from diversity. 1st ed. Jessica Kingsley Publishers.

Carr, A. (2016). An exploratory study of test anxiety as it relates to the national clinical mental health counseling examination. Scholar Commons. University of South Florida. https://scholarcommons.usf.edu/etd/6201

Ceralde, A. (2014). Predictors of performance in the National Qualifying Examination for school heads (NQESH) in the six division of Pangasinan. https://www.academia.edu/36990303/Predictors_of_Performance_in_the_National_Qualifying_Examination_f or_Principals

Charmaz, K. (2006). Constructing grounded theory: A practical guide through qualitative analysis. SAGE Publications.

Childs, R., Ross, M., \& Jaciw, A. (2002). Initial teacher certification testing: pre-service teachers' experiences and perceptions. Canadian Journal of Education, 27(4), 455-475. https://files.eric.ed.gov/fulltext/EJ728304.pdf

Clarke, V., \& Braun, V. (2013). Successful qualitative research: A practical guide for beginners. SAGE Publications, Inc.

Creswell, J. (2014). Research design : qualitative, quantitative, and mixed methods approaches $4^{\text {th }}$ Ed. SAGE Publications, Inc.

Cuevas, C. (2016). Cultural roots of the Philippine educational system. https://www.academia.edu/31267872/Cultural_Roots_of_the_Philippine_Educational_System

Dagdag, J., Sarmiento, C., \& Ibale, J. (2017). Examining the factors of licensure examination for teachers performance for program strategy enhancement. Asia Pacific Journal of Multidisciplinary Research, 5 (4), 34-39. https://www.apjmr.com/wp-content/uploads/2017/12/APJMR-2017.5.4.2.05.pdf

Department of Education. (2007). DepEd Order No. 42. The revised guidelines on selection, promotion and designation of school heads. https://www.deped.gov.ph/2007/07/04/do-42-s-2007-The revised guidelines on selection, promotion and designation of school heads/

Department of Education. (2009). DepEd Memo No. 140. Corrigendum to DepEd Memorandum No. 97, s. 2009: 2009 National Qualifying Examination for Principals. https://www.deped.gov.ph/2009/04/02/april-2-2009- dm-140- 
s-2009-corrigendum-to-deped-memorandum-no-97-s-2009-2009-national-qualifying-examination-forprincipals/

Department of Education. (2009). DepEd Order No. 36. Strict compliance with passing the Qualifying Examination for Principalship for appointment to Principal I position. https://www.deped.gov.ph/2009/04/20/do-36-s-2009strict-compliance-with-passing-the-qualifying-examination-for-principalship-for-appointment-to-principal-Iposition/

Department of Education. (2010). DepEd Order No. 24. Basic Education Research Fund. https://www.deped.gov.ph/wp-content/uploads/2010/03/DO-No.-24-s.-2010.pdf

Department of Education. (2010). DepEd Order No. 32. National adoption and implementation of the National Competency-Based Standards for School Heads. https://www.deped.gov.ph/2010/04/16/do-32-s-2010national-adoption-and-implementation-of-the-national-competency-based-standards-for-school-heads/

Department of Education. (2018). DepEd Memo No. 93. Result of the 2017 principal's test. https://www.deped.gov.ph/2018/05/28/may-28-2018-dm-93-s-2018-results-of-the-2017-principals-test/

Executive Order 201 (2016). Modifying the salary schedule for civilian government personnel and authorizing the grant of additional benefits for both civilian and military and uniformed personnel. https://www.officialgazette.gov.ph/2016/02/19/executive-order-no-201-s-2016/

Flora, I. (2019). Search on for outstanding Central Luzon teachers and school heads. Sunstar. https://www.sunstar.com.ph/article/1821800

Galiza, J., Nicdao R., \& Guidote, A. (2018). Educational attainment, teaching experience, professional development and self-efficacy as predictors of chemistry content knowledge: Implication for the development of a national promotion examination. Kapisanang Kimika ng Pilipinas, (29) 2, 7-22. https://doi.org/10.26534/kimika.v29i2.7-22

Gezahegn, H. (2019). The role of school principals in improving students' academic performance in secondary schools of Sidama Zone, SNNPR. Global Journal of Management and Business Research: G Interdisciplinary, 19 (2). https://journalofbusiness.org > article > download.

Griffiths, M. J., Papastrat, K., Czekanski, K., \& Hagan, K. (2004). The lived experience of NCLEX failure. Journal of Nursing Education, 43(7), 322-325. https://repository.up.ac.za/bitstream/handle/2263/24285/Complete.pdf? sequence $=8 \&$ is Allowed $=\mathrm{y}$

Gorjup, M., Valverde, M., \& Ryan, G. (2009). Promotion in call centers: Opportunities and determinants. Journal of European Industrial Training, (32) 1, 45-62. https://doi.org/10.1108/03090590810846566

Gulek, N. (2003). Preparing for high-stakes testing. Theory Into Practice, 42(1), 42-50. https://www.researchgate.net/publication/233055397_Preparing_for_High-Stakes_Testing. https://doi.org/10.1207/s15430421tip4201_6

Haykal, M. (2015). Family support is the most significant factor in people success. https://www.kompasiana.com/muhammadhaykal/54f6b5e7a33311ea5a8b478c/family-support-is-the-mostsignificant-factor-in-people-success 
Holloway, J.H. (2001). Grouping students for increased achievement. Educational $\quad$ Leadership, $\quad 59(3), \quad 84$. https://eric.ed.gov/?id=EJ636991

Jalagat, R. Jr. (2016). Performance in CPA board examination: Benchmarking for opportunities to meet market demands. International Journal of Social Science and Economic Research, 1(09), 1374-1375. http:// www.ijsser.org

Kadtong, M. (2014). Work performance and job satisfaction among teachers. International Journal of Humanities and Social Science, 3(5),245-252. ～https://www.ijhssnet.com/journals/Vol_3_No_5_March_2013/25.pdf

Katz, J. (2004). Everyday lives and extraordinary research methods. Social Science Information, 43 (4), 609-619. https://doi.org/10.1177/0539018404047707

Kaufman, B. (2011). Why inspiration matters. Harvard Business Review. https://hbr.org/2011/11/why-inspirationmatters

Kelley, C., Heneman, H., \& Milanowski, A. (2000). School-based performance award programs, teacher motivation, and school performance: Findings from a study of three programs. Consortium for Policy Research in Education. $\quad$ https://www.researchgate.net/publication/234744466_SchoolBased_Performance_Award_Programs_Teacher_Motivation_and_School_Performance_Findings_from_a_Stu dy_of_Three_Programs_CPRE_Research_Report_Series

Kovenklioglu, G., \& Greenhaus, J. (1978). Causal attributions, expectations, and taskperformance. Journal of Applied Psychology, 63(6), 698-705. https://doi.org/10.1037/0021-9010.63.6.698

Locke, E. \& Latham G. (1990). Goal setting theory. Organizational Behavior and Human Decision Processes, 50, 212-247. https://doi.org/10.2307/258875

Maghuyop, R. (2015). To pass or fail: A University of Mindanao librarian licensure performance study. University of Mindanao International Multidisciplinary Research Journal, 1(1), 90-104. https:// uminjournals.org

Manik, E. \& Sidharta, I. (2017). The impact of motivation, ability, role perception on employee performance and situational factor as moderating variable of public agency in Bandung, Indonesia. International Journal of Management Science $\quad$ and Business Administration, 3(4), 64-73. https://doi.org/10.18775/ijmsba.18495664-5419.2014.34.1008

Map of Zamboanga Sibugay. (2020). Zamboanga Sibugay. https://en.wikipedia.org/wiki/Zamboanga_Sibugay

Maslow, A. (1943). A theory of human motivation. Psychological Review, 50, 370-396. https://psychclassics.yorku.ca/Maslow/motivation.htm

McClelland, D. (1961). The achieving society. Social Forces, 41(2),208-209. https://doi.org/10.2307/2573612

McFarquhar, C. (2006). Registered nurses' perceptions of factors leading to success on multiple attempts on the National Council Licensure Examination- Registered Nurse (NCLEX-RN). Proquest. (UMI:3207615) https://dissexpress.proquest.com/dxweb/results.html?QryTxt=\&By=McFarquhar2C+C\&Title=\&pubnum=

McLeod, S. (2014). Likert scale. Simplypsychology.org. https://www.simplypsychology.org/Likert-scale.html/pdf 
Morgan, D. (2007). Paradigms lost and pragmatism regained: Methodological implications of combining qualitative and quantitative methods. Journal of Mixed Methods Research, 1(1), 48-76. https://doi.org/10.1177/2345678906292462

Morin, A. (2017). 5 ways to stop resenting other people's success. Forbes Careers Newsletter. https://www.forbes.com/sites/amymorin/2017/01/22/5-ways-to-stop-resenting-other-peoplessuccess/\#6f3566fe4776

Olaniran, T. (2013). Academic excellence seminar: Examination techniques. https://www.academia.edu/6291400/Why_Students_Fail_Examination?auto=download

Otuko, H., Gabriel, K., \& Douglas, M. (2013) The effect of training and ability on the performance of employee at Disaster Management Bureau of Central Kalimantan Province. Mediterranean Journal of Social Sciences, 8(3), 87-90. https://doi.org/10.5901/mjss.2017.v8n3p87

Pattaguan, E. J. (2016). To be on top: A sustained outcomes-based accountancy education experience. Journal of $\begin{array}{lllll}\text { Business } & \text { Studies } & \text { Quarterly, } & 7(3), & \text { 127-151. }\end{array}$ https://media.proquest.com/media/pq/classic/doc/4013045371/fmt/pi/rep/NONE? _s=ydmlSLfh0siq9ax9tf59DC3v0v8\%3D

[Photo of a man driving a sports car]. https://www.123rf.com/photo_50969571_stock-vector-cartoon-illustration-of-aman-driving-a-sports-car-.html

Poorman, S.\& Webb, C. (2000). Preparing to retake the NCLEX-RN: The experience of graduates who fail. Nurse Educator, 25(4), 175-180. https://doi.org/10.1097/00006223-200007000-00013

Punsalan, T. (2012). National Competency-based Standards for School Heads: Training and development needs assessment. https://antiquedeped.weebly.com/uploads/2/0/1/0/20102653/ncbssh-tdna_e-version_antique.xls

Quiambao, D., Baking, E., Buenviaje, L., Nuqui, A., \& Cruz, R. (2015). Predictors of board exam performance of the DHVTSU College of Education graduates. Journal of Business \& Management Studies, 1(1). 1-4. https://www.academia.edu/30430969/PREDICTORS_OF_BOARD_EXAM_PERFORMANCE_OF_THE_DH VTSU_COLLEGE_OF_EDUCATION_GRADUATES

Refugio, C. (2017). Predictors of the Licensure Examination for Teachers: Proposed regression model. Research Gate Publication. https://doi.org/10.13140/RG.2.2.36249.31846

Republic Act No. 6713 (1989). An Act establishing a code of conduct and ethical standards for public officials and employees, to uphold the time-honored principle of public office being a public trust, granting incentives and rewards for exemplary service, enumerating prohibited acts and transactions and providing penalties for violations thereof and for other purposes. https://www.lawphil.net/statutes/repacts/ra1989/ra_6713_1989.html

Republic Act No. 7836 (1994). An Act to strengthen the regulation and supervision of the practice of teaching in the Philippines and prescribing a Licensure Examination for Teachers and for other purposes. https://www.prc.gov.ph/uploaded/documents/PROFESSIONAL\%20TEACHERS-LAW1.PDF

Republic Act No. 8973 (2000). An Act creating the Province of Zamboanga Sibugay from the Province of Zamboanga del Sur and for other purposes. https://thecorpusjuris.com/legislative/republic-acts/ra-no-8973.php 
Republic Act No. 9155 (2011). An Act instituting a framework of governance for basic education, establishing authority and accountability, renaming the Department of Education, Culture and Sports as the Department of Education and for other purposes. https://www. lawphil.net/statutes/repacts/ra2001/ra_9155_2001.html

Rescher, N. (1995). The brilliant randomness of everyday life. Kirkus Reviews. https://www.kirkusreviews.com/book-reviews/nicholas-rescher/luck/

Ryan, R. \& Deci, E. (2000). Intrinsic and extrinsic motivations: Classic definitions andnew directions. Contemporary Educational Psychology 25, 54-67. https://doi.org/10.1006/ceps.1999.1020

Sadiq, A. \& Saeed, M. (2017). An exploratory study on problems faced by students during board examination. Bulletin of Education and Research, 39 (1), 101-115. https://pu.edu.pk/images/journal/ier/PDFFILES/8_39_1_17.pdf

Saif, K.F., Nawaz, A., Jan, A., \& Khan, M.I. (2012). Synthesizing the theories of job-satisfaction across the cultural/attitudinal dimensions. Interdisciplinary Journal of Contemporary Research in Business, 3 (9), 13821396. https://doi.org/10.18775/ijied.1849-7551-7020.2015.33.2004

Saldaña, J. (2010). Coding and data analysis during qualitative empirical research in practical theology. https://doi.org/10.4102/ids.v49i3.1880

SeameoInnoctech. (2009). Seameo Innotech executive report 2008-2009. https://www.seameo.org/SEAMEOWeb2/images/stories/SEAMEO_General/About_SEAMEO/SEAMEO\%20 Units/Centres_Annual_Rpt/2008-2009/INNOTECH_exe_2008_2009.pdf

Silm G., Must O., \& Täht, K. (2013). Test-taking effort as a predictor of performance in low-stakes tests. Trames Journal of the Humanities and Social Sciences, 17(67) 433-448. https://doi.org/10.3176/tr.2013.4.08

Silva, C. (2015). The lived experience of graduate nurses with multiple NLCEX-RNfailure. Indiana University of Pennsylvania Knowledge Repository @ IUP. https://pu.edu.pk/images/journal/ier/PDF-FILES/8_39_1_17.pdf

Singh, S., Malik, S., \& Singh, P. (2016). Factors affecting academic performance of students. Indian Journal of Research, 5(4), 176-178. https://www.researchgate.net/publication/301324970

Sobotka, V. (2017). Future educators' preparation and well-Being: A qualitative study. Honors Theses. 154. https://pdfs.semanticscholar.org/ d733/ 7deb54f3bbea73fe212b3ff2cd645fcf272f.pdf

Strauss, A. (2001). Qualitative analysis for social scientists. Cambridge University Press. https://www.academia.edu/7430069/Anselm_L._Strauss_Qualitative_ Analysis_for_Social_Scientists_1987

Tan, J. (2014). Academic performance, aspirations, attitudes and study habits as determinants of the performance in the Licensure Examination of Accountancy graduates. International Journal of Education and Research, 2 (12) 61-70.https://doi.org/10.21016/IRRC.2014.14NTT032

Vaz C., Kamath A., \& George, L. (2018). Factors influencing examination anxiety among undergraduate nursing students: An exploratory factor analysis. Journal of Clinical and Diagnostic Research, 12(7)16-19, https://www.researchgate.net/publication/326394218. https://doi.org/10.7860/JCDR/2018/35878.11817. 
Visco, D. (2015). Determinants of performance in the Licensure Examination for Teachers (LET) of Abra State Institute of Sciences and Technology. International Journal of Research in Management \& Business Studies, 2(1), 39-44. https://ijrmbs.com/vol2issue1/dionisio.pdf

Weiner, B. (1985). An attributional theory of achievement, motivation and emotion. Psychological Review, 92 (4), 548-573. https://doi.org/10.1037/0033-295X.92.4.548

Wooi, T. (2015). Global school methodologies. Paper presented at the Concourse Convention Center, Legazpi City. https://www.slideshare.net/timothywooi/global-school-management-methodologies

Yusefzadeh, H., Amirzadeh, J., \& Nabilou, I. (2017). The effect of study preparation on test anxiety and performance: a quasi-experimental study. Dove Press Journal: Advances in Medical Education and Practice, (10). 245-251. http://doi.org/10.2147/AMEP.S192053 